IZA DP No. 8043

Does Grief Transfer across Generations? In-Utero Deaths and Child Outcomes

Sandra E. Black

Paul J. Devereux

Kjell G. Salvanes

March 2014 


\title{
Does Grief Transfer across Generations? In-Utero Deaths and Child Outcomes
}

\author{
Sandra E. Black \\ University of Texas at Austin, \\ NHH, CESifo, IZA and NBER \\ Paul J. Devereux \\ University College Dublin, \\ CEPR and IZA \\ Kjell G. Salvanes \\ Norwegian School of Economics, \\ Statistics Norway, CEP, CESifo and IZA \\ Discussion Paper No. 8043 \\ March 2014 \\ IZA \\ P.O. Box 7240 \\ 53072 Bonn \\ Germany \\ Phone: +49-228-3894-0 \\ Fax: +49-228-3894-180 \\ E-mail: iza@iza.org
}

Any opinions expressed here are those of the author(s) and not those of IZA. Research published in this series may include views on policy, but the institute itself takes no institutional policy positions. The IZA research network is committed to the IZA Guiding Principles of Research Integrity.

The Institute for the Study of Labor (IZA) in Bonn is a local and virtual international research center and a place of communication between science, politics and business. IZA is an independent nonprofit organization supported by Deutsche Post Foundation. The center is associated with the University of Bonn and offers a stimulating research environment through its international network, workshops and conferences, data service, project support, research visits and doctoral program. IZA engages in (i) original and internationally competitive research in all fields of labor economics, (ii) development of policy concepts, and (iii) dissemination of research results and concepts to the interested public.

IZA Discussion Papers often represent preliminary work and are circulated to encourage discussion. Citation of such a paper should account for its provisional character. A revised version may be available directly from the author. 


\section{ABSTRACT}

\section{Does Grief Transfer across Generations? In-Utero Deaths and Child Outcomes*}

While much is now known about the effects of physical health shocks to pregnant women on the outcomes of the in-utero child, we know little about the effects of psychological stresses. One clear form of stress to the mother comes from the death of a parent. We examine the effects of the death of the mother's parent during pregnancy on both the short-run and the long-run outcomes of the infant. Our primary specification involves using mother fixed effects - comparing the outcomes of two children with the same mother but where a parent of the mother died during one of the pregnancies - augmented with a control for whether there is a death around the time of the pregnancy in order to isolate true causal effects of a bereavement during pregnancy. We find small negative effects on birth outcomes, and these effects are bigger for boys than for girls. The effects on birth outcomes seems to be driven by deaths due to cardiovascular causes suggesting that sudden deaths are more difficult to deal with. However, we find no evidence of adverse effects on adult outcomes. The results are robust to alternative specifications.

\section{JEL Classification: I1, I2, J1}

Keywords: $\quad$ stress, birthweight, education, pregnancy

Corresponding author:

Sandra E. Black

Department of Economics

1 University Station \#C3100

University of Texas at Austin

Austin, TX 78712

USA

E-mail: sblack@austin.utexas.edu

\footnotetext{
* We are grateful to the Norwegian Research Council for support, the Medical Birth Registry of Norway for providing the birth registry data, and to participants at the workshop in Family Economics in Bergen in 2013, and seminar participants at the University of Texas, Norwegian School of Economics, and UCL for comments.
} 
Much is now known about the effects of shocks to the physical health of pregnant women on the outcomes of the in-utero children, with evidence that adverse health or nutrition shocks to pregnant women have significant and often long-lasting effects on the outcomes of their children. ${ }^{1}$ However, much less is known about the effects of psychological stresses. This is despite the fact that, in developed countries, this type of stress is likely more prevalent than nutritional deficits during pregnancy. In an article in the New York Times on July 21, 2011 entitled, "The Pregnant Superwoman," the author discusses the role of stress during pregnancy and how society should, or should not, respond. ${ }^{2}$ However, a key underlying assumption of this and other popular discussion is that we have actually identified the effect of stress while pregnant on the children's outcomes, and it is not clear that that is true.

There are a number of mechanisms through which stress can affect a developing fetus. One plausible biological mechanism is that stress triggers the production of a placental corticotrophin-releasing hormone $(\mathrm{CRH})$, which has been shown to lead to reduced gestational age and low birth weight. (Hobel and Culhane, 2003). In addition, stress suppresses the immune system, thereby making pregnant mothers more susceptible to sickness, and can cause high blood pressure, which increases the chance of having pre-term labor or a low birth weight infant. Finally, there may be adverse behavioral responses to stress, such as smoking cigarettes or drinking alcohol, which can also have adverse effects on the health of the fetus.

In general, it is difficult to identify the causal effect of stress due to the difficulty of separating out the stress effect from the direct effect of the event causing the stress (natural disaster exposure, for example). In this paper, we use register data on the population of Norway

\footnotetext{
${ }^{1}$ See Almond and Currie (2010) and Currie (2011) for surveys of some of this work.

${ }^{2}$ Belkin, Lisa, "Myth of the Pregnant Superwoman" July 21, 2011.

http://parenting.blogs.nytimes.com/2011/07/21/myth-of-the-pregnant-superwoman/
} 
to examine the effect of stress caused by the death of a pregnant woman's parent on both the short-run and long-run outcomes of her children. ${ }^{3}$

While using parental death as a shock to the stress level of the mother eliminates a number of the problems faced by earlier identification strategies, some issues do remain. First, parental death can affect individuals in many ways other than through stress. ${ }^{4}$ In particular, parents may be important sources of educational funding or parents and children may coreside - as a result, parental death might represent a shock to one's lifestyle or income. To reduce the potential impact of these issues, we restrict the sample to women who have children between the ages of 25-45, when they are less likely to be dependent on parental resources. We also conduct a number of specification checks to confirm that it is not the loss of help during the pregnancy that is driving our results.

Second, individuals who have a parent die younger are not a random sample of the population. Lower income families are likely to both have parents who die earlier and poorer child outcomes, both in the short-run and in the longer-run. To deal with this, we integrate two approaches in our estimation strategy. The first is the use of mother fixed effects, thereby comparing two children born to the same mother, with the mother experiencing a parental death during only one of the pregnancies. ${ }^{5}$

However, mother fixed effects may be inadequate if parental deaths are correlated with time-varying characteristics of the mother. Therefore, our estimation strategy also includes a control for whether a death occurs in a short window around the pregnancy. This allows us to

\footnotetext{
${ }^{3}$ The death of a parent of the father may also increase the stress levels of the mother during pregnancy. We have investigated this issue and found no evidence for any adverse effect of such an event on child outcomes.

${ }^{4}$ The death of a parent is generally regarded as a very stressful event. For example, the Holmes-Rahe Stress Inventory treats the death of a close family member as the fifth most stressful life event (the death of a spouse is considered to be the most stressful life event).

${ }^{5}$ Much of the research in the literature on child outcomes has used mother fixed effects, for example Currie and Rossin-Slater (2013).
} 
isolate the effect of a death during pregnancy from the effect of a death in the general time period around pregnancy.

Finally, there is also the mechanical relationship that a parental death is more likely to occur during pregnancy if the gestation period is longer. To account for this, we instrument the occurrence of a death during pregnancy with whether a death occurred during the 9 months following conception.

We find that a parental death experienced while pregnant leads to small negative effects on birth outcomes, including birth weight and APGAR scores, and these effects appear to be bigger for boys than for girls. When we look by cause of death, we find that the effects are largest when cardiovascular disease is the cause of death, tentatively suggesting that more unexpected deaths have bigger adverse effects. However, despite these negative effects at birth, we find no evidence for adverse effects on the children's outcomes later in life, suggesting no persistent negative effects.

The paper unfolds as follows. Section 2 discusses the related literature, while Section 3 describes our empirical strategy. Section 4 describes our data, and Section 5 presents our results for short-run effects on birth outcomes. Section 6 describes the robustness checks and examines heterogeneous effects. In Section 7, we show the longer-run effects on education and wages. Section 8 then concludes.

\section{Related Literature}

There is a large literature examining the effects of physical insults to the mother while pregnant on the outcomes of the children. This includes studies on the effects of the $1918 \mathrm{flu}$ epidemic (Almond, 2006), the 1957 Asian flu pandemic (Kelly, 2011), the 1959 to 1961 Chinese 
famine (Almond, Edlund, Li, and Zhang, 2010), the Dutch famine in 1945-46 (Scholte, van den Berg, and Lindeboom 2012), exposure to radiation (Almond, Edlund and Palme, 2009 and Black, Buetikofer, Devereux and Salvanes, 2013), temperature during gestation (Bruckner et al. 2014), and the effects of maternal smoking and drinking (Currie, Neidell and Schmieder, 2009; Fertig and Watson, 2009). ${ }^{6}$

There is a more limited amount of research examining the effects of stress while pregnant on children's outcomes. The majority of these studies focus on stress induced by large disasters, such as earthquakes (Glynn et al., 2001; Torche 2011), extreme weather events, such as hurricanes (Simeonova, 2011 and Currie and Rossin-Slater, 2013), the terrorist attacks of 9/11 (Berkowitz et al., 2003, and Lauderdale, 2006), and the prevalence of landmines in Columbia (Camacho, 2008). These studies tend to find a negative effect of stress on children's outcomes at birth. However, a key limitation of this work is that these disasters may have direct effects on the pregnant women, and hence the effects we observe are due to the combination of the direct (physical) and indirect (through stress) effects on the mother.

There are a number of exceptions. Aizer, Stroud and Buka (2012) use a sample of pregnancies from the early 1960s in Providence and Boston and estimate sibling fixed effects models of the effects of cortisol levels (a marker for maternal stress) during pregnancy on educational attainment. While this study has the advantage of having a direct measure of stress (cortisol levels), it is somewhat limited by small sample sizes. Additionally, there remains the concern that stress levels are correlated with unobserved events that have direct effects on the mother.

There are also a few papers that examine the effect of stress resulting from the death of someone close to the pregnant mother on the birth outcomes of the children. Catalano and

\footnotetext{
${ }^{6}$ See Currie (2011) for a review.
} 
Hartig (2001) examine the effect of the assassination of Olaf Palme in Sweden on pregnancy outcomes just after but need to rely on time-series variation. Importantly, because we have information on all Norwegian deaths, we can fully control for month and year of birth. Using micro data from Denmark, Li et al. (2010) compare the Body Mass Index (BMI) of children of mothers who experienced a death during pregnancy to children of those who did not. However, a key limitation is that this study does not deal with the non-random timing of fertility or deaths. Our paper attempts to isolate the causal effect of stress by taking into account the non-random timing of fertility and deaths.

\section{Empirical Approach}

As previously noted, because family deaths are not randomly assigned, a simple regression of birth weight on an indicator of whether the mother experienced the death of a parent while pregnant may lead to inconsistent estimates of the effect of stress on birth outcomes. Poorer families have lower life expectancy, suggesting parents are more likely to die relatively young. Therefore, the existence of a parental death while pregnant is likely to be correlated with the unobserved characteristics of the mother and child. ${ }^{7}$ In order to obtain consistent estimates, we use an estimation method that includes both mother fixed effects and a comparison between the effects of a death during a pregnancy and the effects of a birth immediately before or after.

By incorporating mother's fixed effects, we are exploiting the fact that many mothers have more than one birth during the sample period. If a mother has two births, by chance, one pregnancy might coincide with the death of one of the mother's parents. By comparing the outcomes of the two births, we can evaluate the effect of the death, differencing out any time-

\footnotetext{
${ }^{7}$ Appendix Table 1 presents summary statistics of the characteristics of those mothers who experienced a parental loss while pregnant compared to those who did not.
} 
invariant characteristics of the mother or family background more generally that could bias the results. ${ }^{8}$ In order to implement this design, we restrict the sample to mothers who have at least two births and include mother fixed effects in the regression. ${ }^{9}$

While the mother fixed effect helps eliminate differences in the fixed family characteristics of those who are more likely to lose a parent at a younger age, there may still be time-varying factors correlated with the death of a parent (for example, caring for a sick parent). To address this, we augment the fixed effects approach by including an indicator equal to one if the mother experienced a parental death at any point in the period right before, during, or right after pregnancy. For mothers who experience a parental death either during pregnancy or just before or after pregnancy, it may be a matter of chance whether the death occurs specifically before, during, or after pregnancy. Therefore, conditional on a death around the time of pregnancy, whether or not the death occurs during pregnancy can be considered to be random. With this control, the indicator for death during pregnancy now reflects the additional effect of having a death during pregnancy.

We implement this approach by choosing a window based on the conception date (as gestation is potentially endogenous). Our benchmark window includes all births in which a grandparent death occurs in the year before the conception date, during the 9-month interval after the conception date, or in the year immediately following this 9-month interval. Appendix Table 2 presents summary statistics by the timing of parental death to provide a basic sense of the comparison we are making — we are essentially comparing the outcomes for those children

\footnotetext{
${ }^{8}$ To the extent that the investment behavior of mothers responds to the relative endowments of her children, estimates using mother fixed effects may be biased. Compensating responses could reduce endowment effects while re-enforcing behavior would increase them. Clearly, investment responses by parents are a much bigger issue for later child outcomes than they are for birth outcomes that are realized before the child's endowment is known. ${ }^{9}$ Table 1 provides a comparison of the summary statistics of the full sample of births and our reduced sample, where the restriction we impose is that there must be at least two births for each mother. Based on observable characteristics, the samples look quite similar.
} 
whose mother experienced a death while pregnant (in utero) relative to those who experienced it just before or after—and, observably, these groups are quite similar. However, in the regressions, we also include mother fixed effects to control for any unobserved mother characteristics that might be related to the probability of experiencing a death during pregnancy.

A final issue that arises in estimating the effect of a pregnant woman's parental death on children's outcomes is the mechanical relationship between duration of pregnancy and probability of experiencing a death. While gestation generally lasts about 9 months, it varies across pregnancies. If a pregnancy lasts longer, it is more likely that a grandparent death occurs during the gestation period. This leads to a mechanical positive relationship between a death in utero and gestation length. Given that gestation is correlated with birth weight and other birth outcomes, this relationship biases against finding a negative effect of family deaths on birth outcomes.

We deal with this issue by adopting an instrumental variable strategy used by Currie and Rossin-Slater (2013). Since we observe gestation length in the data, we can figure out the conception date counting backwards from the birth date. We create a predicted gestation period as the period from the conception date until 9 months after the conception date and measure family deaths that take place during this period. We then use family deaths in this predicted gestation period as an instrument for family deaths during the actual gestation. In practice, the first stage relationship is extremely strong so the instrumental variables estimates are very similar to the reduced form.

The equation we estimate is as follows:

$$
H_{i f t}=\alpha_{0}+\alpha_{1} D W_{i t}+\alpha_{2} D_{i t}+\beta X_{i t}+\gamma_{t}+\lambda_{f}+\epsilon_{i f t} .
$$


Here $H_{\text {ift }}$ represents outcomes, such as birth weight, for child $i$ from family $f$ at time $t . D W$ is an indicator variable for whether there was a death (of a parent of the mother) in the window around pregnancy (in the year before, during the pregnancy, or in the year afterwards) and $D$ is our variable of interest--an indicator for whether there was a death while the child was in utero. $X$ is a vector of controls that includes age of mother at birth (in years), birth order of the child, years of education of both father and mother, and the gender of the child. We also include controls for year of birth by month of birth indicators $\left(\gamma_{t}\right)$. Note that, in our main specification, we additionally include $\lambda_{f}$, a mother fixed effect. In the fixed effects specifications, we exclude mother's education because it is time invariant and mother's age at birth as it is subsumed by the year of birth by month of birth dummies. We estimate this using OLS; in the case of binary dependent variables, we are estimating linear probability models. ${ }^{10}$

Our approach requires two main assumptions: The first assumption is that the unobserved characteristics of the pregnancy are uncorrelated with whether a death is going to occur during it rather than just before or after it (conditional random assignment). Given we have mother fixed effects, unobserved characteristics of the mother are not an issue. This assumption would be violated if deaths just before the in-utero period influenced the pregnancy decision so as to make the timing of pregnancy endogenous.

The second assumption required is that there is no direct effect of a death just outside the in-utero window on child outcomes (exclusion condition). This is not testable and, if there is a negative effect on the child of a death immediately post-utero, this would bias down our estimated effect. This is a potential problem for studying later outcomes but not a problem for

\footnotetext{
${ }^{10}$ One complication that arises is that the father of the children could potentially be different across births. Therefore, we include controls for paternal education. We also tested the robustness of our results when we restrict the sample to siblings with the same father; results are insensitive to this constraint.
} 
studying birth outcomes like birth weight. Another potential issue is that the grandparent may be dying during the in-utero period but die afterwards and this would lead to downward bias. While we do not have data on grandparent health, we do examine whether the effects differ by cause of death and find that there are bigger adverse effects when the death is more likely to be unexpected.

\section{Data}

\section{Birth Records}

Our primary data source is the Medical Birth Registry of Norway that includes the birth records for all Norwegian births from 1967 to 2009. All births, including those born outside of a hospital, are included as long as the gestation period was at least 12 weeks. The birth records contain information on year and month of birth, birth weight, gestational length, age of mother, and a range of variables describing infant health at birth. ${ }^{11}$ In these data, we are also able to distinguish between singleton and multiple births, and we exclude multiple births from the sample.

\section{Death Records}

The Norwegian Death Register has information on deaths that occur in Norway between 1961 and 2010. For each death, we know the exact date of death and the cause of death. Using the individual identifiers, we can merge date of death to other information about the individual.

\section{Other Register Data}

Using unique personal identifiers, we match the birth and death files to the Norwegian Registry Data, a linked administrative dataset that covers the population of Norwegians alive at

\footnotetext{
${ }^{11}$ We do not know the exact date of birth - in the empirical work we treat births as taking place on the $15^{\text {th }}$ day of each month.
} 
any point between 1960 and 2010 and is a collection of different administrative registers such as the education register, family register, and the tax and earnings register. These data are maintained by Statistics Norway and provide information about educational attainment, labor market status, earnings, and a set of demographic variables (such as age and gender) as well as information on families.

\section{Military Data}

We are also able to match the birth records to the Norwegian military records from 1984 to 2010 that contain information on height, weight, and IQ scores. In Norway, military service is compulsory for every able young man. Before entering the service, their medical and psychological suitability is assessed; this occurs for the great majority between their eighteenth and twentieth birthday. ${ }^{12}$ We match these data with our other data files and use the height, Body Mass Index (BMI - defined as kilograms divided by meters squared), and test score data as outcome variables for men. $^{13}$

\section{Outcomes}

We study a variety of different outcomes, both at birth and later in life. One of the key variables we examine is birth weight, available beginning in 1967. In the literature, different variants of birth weight have been used as the primary variable of interest. These include birth weight, $\log$ (birth weight), and fetal growth (defined as birth weight divided by weeks gestation). Given that there is no obvious choice a priori, we report estimates for all of these variables in our

\footnotetext{
${ }^{12}$ Of the men in the 1967-1987 birth cohorts, 1.2 percent died before 1 year and 0.9 percent died between 1 year of age and registering with the military at about age 18. About 1 percent of the sample of eligible men had emigrated before age 18, and 1.4 percent of the men were exempted because they were permanently disabled. An additional 6.2 percent are missing for a variety of reasons including foreign citizenship and missing observations. See Eide $e t$ al. (2005) for more details.

${ }^{13}$ There is an extensive literature suggesting that height is a useful indicator of health, both in developed as well as developing nations. See Strauss and Thomas (1998) for references.
} 
analysis. ${ }^{14}$ In our 2007 study of the effect of birth weight on adult outcomes (Black, Devereux, and Salvanes, 2007), we found that, of these measures, $\log ($ birth weight) was the best predictor of future educational attainment, cognitive scores, and earnings. Therefore, we emphasize estimates for this outcome measure. ${ }^{15}$ In our main specifications, we also report effects of parental death on weeks of gestation and the height of the baby at birth, all available beginning in 1967.

To augment these results, we also incorporate a number of other characteristics of the birth or the first weeks of life that are reported in the Birth Register. A key indicator of health at birth is the 5-minute APGAR score. APGAR scores are a composite index of a child's health at birth and take into account Activity (and muscle tone), Pulse (heart rate), Grimace (reflex irritability), Appearance (skin coloration), and Respiration (breathing rate and effort). Each component is worth up to 2 points for a maximum of $10 .{ }^{16} \mathrm{We}$ also study whether the birth was via Caesarian section, and whether the child was in the Neonatal intensive care (NICU) after birth. ${ }^{17}$ We consider both of these as potentially reflecting the presence of problems at birth that may be associated with poor infant health.

Among the long-run outcomes, for the cohorts of men born from 1967 up to 1991 we have information from the military records on height and BMI, both of which were measured as part of the medical examination. The military records also contain an IQ score. The IQ measure is the mean score from three IQ tests -- arithmetic, word similarities, and figures (see Sundet $e t$ al. [2004, 2005] and Thrane (1977) for details). The arithmetic test is quite similar to the

\footnotetext{
${ }^{14}$ The incidence of low birth weight ( $<2500$ grams) is also frequently studied in the literature. Only $3 \%$ of our sample is low birth weight and we have found tiny insignificant effects when we have looked at the effect of parental deaths on this variable.

${ }^{15} \mathrm{We}$ set birth weight to missing in cases where it is reported to be less than 500 grams.

${ }^{16}$ Apgar scores are available in the birth records beginning in 1977.

${ }^{17} \mathrm{We}$ don't report results for infant mortality as it is very rare in our sample (less than $1 \%$ of births). When we have used it as an outcome we found tiny insignificant effects.
} 
arithmetic test in the Wechsler Adult Intelligence Scale (WAIS) (Sundet et al. 2005; Cronbach 1964), the word test is similar to the vocabulary test in WAIS, and the figures test is similar to the Raven Progressive Matrix test (Cronbach 1964). The IQ score is reported in stanine (Standard Nine) units, a method of standardizing raw scores into a nine point standard scale that has a discrete approximation to a normal distribution, a mean of 5 , and a standard deviation of $2 .^{18}$

For both men and women, we study years of education for the cohorts born between 1967 and 1985 (and who are therefore at least 25 in 2010). Our measures of educational attainment are reported by the educational establishment directly to Statistics Norway, thereby minimizing any measurement error due to misreporting. ${ }^{19}$ We also create a binary indicator for whether the person has at least 12 years of education. For this variable, we include persons aged at least 21 in 2010 so we have cohorts up to 1989.

Finally, we are also able to look at labor market outcomes for both men and women. We first consider attachment to the labor force by studying whether individuals who are at least 25 years old are full-time, full-year workers in 2010 (the last year of our panel). To identify this group, we use the fact that our dataset identifies individuals who are employed and working full time (30+ hours per week) at one particular point in the year (in the second quarter in the years 1986-1995, and in the fourth quarter thereafter). ${ }^{20} \mathrm{We}$ label these individuals as full-time workers; about $60 \%$ of persons in our sample work full time in 2010 .

We also study the earnings of individuals who are at least 25 years old and full-time fullyear employees in 2010, measured as total pension-qualifying earnings reported in the tax

\footnotetext{
${ }^{18}$ The correlation between this IQ measure and the WAIS IQ score has been found to be 0.73 (Sundet et al., 2004).

${ }^{19}$ See Møen, Salvanes and Sørensen (2003) for a description of these data.

${ }^{20} \mathrm{An}$ individual is labeled as employed if currently working with a firm, on temporary layoff, on up to two weeks of sickness absence, or on maternity leave.
} 
registry. These are not topcoded and include labor earnings, taxable sick benefits, unemployment benefits, parental leave payments, and pensions.

\section{Sample Restrictions}

We restrict our sample to include only births where the mother is between 25 and 45 years old at the time of birth, drop multiple births, and drop cases with missing information on the control variables or with missing identifiers for the parents of the mother. We also include only live births where gestation length is at least 26 weeks, although we later test the sensitivity of our results to this restriction. Because we primarily use specifications with mother fixed effects, we limit our analysis sample to mothers who have at least two births in the sample; Table 1 presents summary statistics for the full sample of births and for the mother fixed effect sample (what we call the analysis sample). The means of most variables are similar in the two samples but parents in the analysis sample have higher education and their children tend to have better average outcomes. ${ }^{21}$ The analysis sample is used for all subsequent empirical work in this paper.

It is likely that there are systematic differences between the types of mothers who experience a parental death during pregnancy and other mothers. Appendix Table 1 provides some information on this for our analysis sample. Clearly there are some systematic differences - pregnancies that have a death involve parents who are older and less educated than other pregnancies. Also, pregnancies with a death are less likely to occur later in the sample period. In addition to mother fixed effects, we control for all of these variables in estimation. Note that this highlights the importance of comparing two pregnant women who both experienced deaths, one of which happened while the baby was in utero and the other occurred just before or after the pregnancy.

\footnotetext{
${ }^{21}$ As is shown in Appendix Table 6, OLS estimates without mother fixed effects are similar in the two samples so there is little reason to believe that our results are not generalizable.
} 


\section{Results}

The first 3 rows of Table 2 present "naïve" cross-sectional OLS estimates without mother fixed effects for our analysis sample, demonstrating the importance of instrumenting for death during pregnancy with death during the 9 months after conception. The first row presents the "naïve" OLS results of the effect of a grandparent death while in utero for each outcome, the second row presents the reduced form when an indicator of death of grandparent in utero is replaced with an indicator for death of a grandparent up to 9 months after conception, and the third row presents the results when death of a grandparent in utero is instrumented with an indicator for death of a grandparent within 9 months after conception. In all specifications, we control for maternal and paternal education, age of mother at birth, birth order of the child, gender of the child, and year by month of birth indicators.

The upward bias of "naïve" OLS due to the spurious relationship between gestation length and family deaths is obvious in the estimates. This is particularly apparent when weeks pregnant is the dependent variable, as the sign flips from positive to negative when we go from OLS to IV. ${ }^{22}$ While the first stage is not reported, the first stage coefficient is close to one, leading the reduced form and IV estimates to be very similar. While these estimates generally show adverse effects of a death on birth outcomes, we do not focus on these results because the specification does not allow for unobserved factors that may be correlated with timing of fertility and bereavement.

As mentioned earlier, to address issues of selection, we implement a mother fixed effects strategy and also include a control variable for whether there is a death in the window around

\footnotetext{
${ }^{22}$ To reassure that the magnitude of the change is reasonable, we have implemented a small monte carlo using a distribution of gestation lengths and a grandparent death rate that matches those in our sample. We found differences between "naïve" OLS and IV estimates that mimic those we find in Table 2 for weeks gestation, suggesting that the differences between OLS and IV results are driven by the mechanical relationship between gestation length and the probability of a death during pregnancy.
} 
pregnancy. We first present the results from specifications where we include mother fixed effects (IV FE, Row 4 of Table 2), then the effect of death in utero controlling for whether there is a death in the window around the pregnancy (IV Window, Rows 5 and 6 of Table 2) and, finally, the specification that includes both (IV Window FE, Rows 7 and 8). Note that all estimates instrument for death during pregnancy with death in the 9 months post-conception. While the results are surprisingly robust to choice of specification, we focus on our preferred specification, which includes both mother fixed effects and an indicator for whether there was a death in the window surrounding the pregnancy.

The first finding is that there is a negative effect of a bereavement in utero on birth weight. To get a sense of the magnitudes, the estimate of the birth weight effect is about 23 grams. This is relative to a mean of about 3500 grams and standard deviation of about 500 grams, so it is approximately $5 \%$ of a standard deviation. The coefficient in the log birth weight regression is about -.007 (note that, for presentation purposes, this estimate is multiplied by 10 in the tables), which implies that a death reduces birth weight by less than $1 \% .{ }^{23}$ These small birth weight effects occur both because of a small reduction in gestation length (by .09 weeks or less than one day) and due to a fall in the rate of fetal growth. The reduction in birth weight is mirrored by a negative effect on birth length (infant height). Once again this effect is very small as the coefficient implies a magnitude of less than one $10^{\text {th }}$ of a centimeter. Overall, our results for birth weight and length imply adverse but very small effects of a grandparent death in utero.

Table 2 also presents results for other birth outcomes. ${ }^{24}$ Again focusing on the specification with both mother fixed effects and an indicator for a death within the window

\footnotetext{
${ }^{23}$ Based on the Black, Devereux, and Salvanes (2007) estimates of the effects of birth weight on adult outcomes, this would imply that a family death reduced the probability of finishing high school and log earnings by only about .0006 and .0008 , respectively.

${ }^{24}$ Because data on APGAR scores begin in 1977, sample sizes are smaller for this outcome.
} 
surrounding the pregnancy, we find that stress leads to a lower 5 minute APGAR score and increased likelihood of having a caesarian section. The effect on the APGAR score is small at about $4 \%$ of a standard deviation but the effect on caesarian section is larger - a death in utero increases the probability of a C-section by about $1 \%$ (from a baseline of about $11 \%$ ). Finally, we find no evidence of any effect on the likelihood of the child being transferred to the Neonatal Ward.

In Table 2, we also report the coefficients on the variable that measures whether there is a death in the window that envelops the pregnancy. It is difficult to interpret these coefficients because they may reflect true causal effects of deaths just before or just after pregnancy, or they could be picking up systematic differences between the unobserved characteristics of pregnancies that occur during periods with a death and periods without a death. Without mother fixed effects, the coefficients are small and statistically insignificant. With mother fixed effects, this variable is statistically significant for most outcomes but the size of the coefficient is always smaller (in absolute terms) than that of the main coefficient of interest. This suggests that, conditional on the mother fixed effects, there is not a lot of selection in terms of which pregnancies are accompanied by deaths. This is consistent with the fact that the estimates in Table 2 are relatively robust, regardless of specification.

\section{Magnitudes}

In terms of how these estimates compare to the existing literature, most credible studies find small negative effects of stress in utero on birth outcomes. Using a family fixed effects strategy, Currie and Rossin-Slater (2013) find no evidence of effects of hurricanes on birth weight or gestation length but some evidence of effects on C-sections and abnormalities. Simeonova (2011) finds a natural disaster reduces birth weight by 1 gram and weeks of gestation 
by .01, and Camacho (2008) finds that living near a landmine explosion in Colombia reduces birth weight by 9 grams. Our findings of small negative effects are in line with these other estimates.

\section{By Cause of Death}

While it is clearly stressful to lose a parent to any cause, there may be some types of deaths that are more stressful than others. For example, more sudden, unexpected deaths, such as those resulting from a heart attack, may lead to more concentrated stress at the time of the passing. Appendix Table 3 presents the causes of grandparent deaths during pregnancy for the analysis sample. As is well known, the two major distinct causes of death are cancers and cardiovascular disease.

To examine whether there are differential effects by cause of death, we include separate dummy variables for each of three causes of death — cardiovascular disease, cancer, and other or unknown. Table 3 presents these results. In this table, and in the remaining tables of the paper, we report estimates from the instrumental variables estimator including both mother fixed effects and the indicator for a death within the window surrounding the pregnancy.

Importantly, we see that the results are clearly being driven by deaths from cardiovascular disease, with larger and statistically significant negative birth outcomes resulting from this cause of death of the mother's parent. There is little evidence of negative birth outcomes related to death by cancer or other causes.

\section{Timing}

Given that stress does seem to matter, we then investigate when during the pregnancy the fetus is most vulnerable. To do so, we divide the pregnancy into trimesters. Table 4 presents the results when we estimate the effect of the death of a grandparent on birth outcomes by trimester 
of exposure. Once again, we only report IV estimates with mother fixed effects and an indicator for death within the window surrounding the pregnancy. The results suggest no clear pattern of timing — while some specifications are statistically significant, the coefficient sizes are relatively constant across the trimesters, leaving us reluctant to draw any strong conclusions about timing. By Type of Grandparent

One concern about our interpretation of a grandparent death as being a source of grief or stress is that grandparents may provide support to the mother during pregnancy (helping with housework, looking after other children etc). While we cannot examine this directly, we can investigate whether the effects vary by grandparent characteristics in a manner that would be consistent with this interpretation. We look at two different splits of the data. The first is whether it is the grandmother or grandfather who dies, with our prior being that the grandmother is likely to provide more direct help to the pregnant daughter and, as a result, her loss might affect the daughter both because of stress and perhaps also a loss of help. We also examine whether the grandparent dies in the same county as the birth occurs, again hypothesizing that grandparents are more likely to provide help for the pregnant daughter if they live nearby.

The estimates by grandparent gender are in Table 5. For most birth outcomes, the grandfather estimate is bigger in absolute terms than the grandmother estimate. The only exception is that the grandmother death coefficient is larger for C-sections. The coefficient estimates are generally not statistically significant for grandmother deaths so there is much stronger evidence for adverse effects of grandfather deaths. If grandmothers are more likely to provide these services than grandfathers, our finding above of a significant effect for grandfathers suggests stress is likely to be driving our results. 
We also look at how the effects of a death differ depending on the proximity of the grandparent to the mother. To do so, we look at differential effects by whether the death occurred in the same county as the birth. ${ }^{25}$ These estimates are presented in Table 6 . While the estimates are sometimes bigger for deaths that occur in the same county, there is no clear pattern, and there is still evidence of adverse effects on birth outcomes when the death occurs in a different county. This re-enforces our view that stress/grief is the important component of the effects of grandparent deaths. Note that these estimates also suggest that it is very unlikely that our results are driven by some common shock like a local flu epidemic that both leads to the death of the grandparent and to adverse consequences for the fetus.

\section{By Child and Mother Characteristics}

There is some evidence in the literature that boys are more vulnerable to insults in utero than are girls (See for example Eriksson et al., 2010). To examine this directly, we interact the death-in-utero variable with the gender of the child. ${ }^{26}$ Note that we also interact the death-inwindow variable with gender and include a control for whether the child is male.

Table 7 presents the estimates with the gender interaction. The results suggest bigger effects for boys than girls. For the birth weight outcomes, fetal growth, and height, the interaction with male is statistically significant and the effect is bigger for boys than girls. Indeed while there is evidence that gestation length is reduced and the probability of C-section is increased for both boys and girls, there is no other evidence that girls are adversely affected by a death.

\footnotetext{
${ }^{25}$ There are 19 counties in Norway. We treat Oslo and Akershus as one county as Akershus contains many suburbs of Oslo.

${ }^{26}$ The alternative approach of splitting the sample by gender gives consistent results but is less efficient as it requires restricting the sample to mothers who have at least two children of the same sex.
} 
We also can examine whether the effects we observe are changing over time- one might expect changes for a number of reasons, including differences in medical technology or differences in stress-management strategies over time. To examine whether this is the case, the first panel in Table 8 interacts death in utero with whether the birth takes place in the second half of the panel i.e. after 1988 (the analogous interaction of death in window with this variable is also included but not reported). The estimates imply that the effects on gestation length are smaller in the second half of the period but the interaction is statistically insignificant (and generally small) for the birth weight and the other birth outcomes.

Finally, there is always the issue of whether individuals with more resources are better able to mitigate negative effects they experience. To examine this, the second panel of Table 8 interacts the death in utero and death in window indicators with whether the mother has relatively high education (greater than 12 years of schooling). There is some evidence here that the effects are, if anything, larger for more educated mothers, but, once again, the interactions are generally statistically insignificant.

\section{Robustness Checks}

Balancing Tests

Appendix Table 4 presents the results when we run balancing tests to verify that there are no observable differences in the characteristics of parents who experience a death while pregnant, conditional on mother fixed effects and having a death in the window enveloping the pregnancy. As we can see from the results, there are no statistically significant differences, suggesting that there are unlikely to be unobservable differences as well.

Before versus After 
One might expect the effects to be different depending on whether the comparison group includes deaths before conception or after birth, as one might expect spillover effects from negative shocks before conception on outcomes later. To examine this more closely, in Appendix Table 5 we separate the control group--in panel 2, it is a death in utero compared to a death in the 12 months before (implemented by including a control variable for a death occurring just before or during pregnancy), and in panel 3 , it is a death in utero compared to a death in the 12 months after (implemented by instead including a control variable for a death occurring just after or during pregnancy). The estimates are very similar in both cases, suggesting that our findings are generally robust to the choice of control group. Including All Pregnancies with at least 12 Weeks of Gestation

One concern is that we are using only live births with at least 26 weeks gestation when creating our sample. To the extent that a bereavement early in a pregnancy may lead to a miscarriage or a stillbirth, we will understate the effect of bereavement on birth outcomes. To address this, we have tried a variety of tests. First, we examined whether or not bereavement increases the probability of a stillbirth, conditional on gestation lasting at least 12 weeks, and found no evidence of an effect. Second, we tried including all pregnancies with at least 12 weeks gestation, whether they are born live or not. ${ }^{27}$ We have estimated specifications where we use this less restrictive sample inclusion criterion and found very similar, if not slightly larger, effects of stress during pregnancy on birth outcomes. This suggests that our results are unlikely to be tainted by differential selection into our sample.

\section{Long-Run Outcomes}

\footnotetext{
${ }^{27}$ Many miscarriages occur before the $12^{\text {th }}$ week of pregnancy. However, the birth register does not have information on pregnancies that last less than 12 weeks.
} 
Given the negative (albeit small) effects of stress on birth outcomes, we next examine whether there are any longer-run effects on children's outcomes. Table 9 presents the results when we estimate the relationship between grandparent death in utero and the long-run outcomes of children. Because of sample size issues, we pool men and women to increase the precision of the estimates and include a dummy variable for child gender. ${ }^{28}$

Perhaps not surprisingly, we find little evidence of any persistent effect of stress experienced in utero on the long-run outcomes of children. If the effects were all coming through birth weight, we can use estimates from our earlier work (Black, Devereux, and Salvanes 2007) to calculate the predicted effect on longer-run outcomes (as described earlier in the paper). When we do this, we find that we would expect incredibly small effects on longerrun outcomes. For example, we would expect a decline in the probability of completing high school of .0007 , a decline in log earnings of full-time workers of .001, and a decline in IQ score of approximately .006. These small effects could not be distinguished from zero with our sample sizes. Of course, there could be multiple channels through which the stress affects outcomes, not just birth weight. However, we are able to reject large effects with our estimates. For example, when we use our preferred specification with mother fixed effects and a control for death in the window, the confidence intervals imply that we can rule out negative effects on completing 12 years or more of schooling of more than 1.6\%, negative effects on full-time earnings of more than $4 \%$, negative effects on IQ score (for men) of more than $7 \%$ of a standard deviation, and negative effects on adult height (of men) of more than half a centimeter. Moreover, the fact that

\footnotetext{
${ }^{28}$ We have tried interactions with a male dummy variable but they are never statistically significant. We do not report any of the battery of heterogenous effects that we did for the birth outcomes because interaction terms are almost always statistically insignificant.
} 
all coefficients are small and are of varying sign provides strong evidence that there are not large effects on later outcomes. $^{29}$

This is an important finding in the context of the existing research in the area. The literature on the effects of physical insults in utero has tended to find adverse effects on both birth outcomes and on later measures of cognitive development, educational attainment, and labor market success. However, the literature on the effects of stress during pregnancy on child outcomes has generally focused on birth outcomes of children and found small adverse effects. We have been left to wonder whether these imply that affected children will also have poorer later outcomes. The death of a parent clearly causes acute stress to pregnant women, but we have found no evidence of significant effects on later outcomes of children. This suggests that, even if there are measurable effects on birth outcomes, we may be able to be more sanguine about the effects of acute psychological stressors on child outcomes.

\section{Conclusion}

While we have substantial evidence that physical health shocks while pregnant have deleterious effects on the outcomes of children, much less is known about the effects of mental health shocks while pregnant on the well-being of the baby. Using unique data from Norway, we are able to estimate the effect of stress induced by the death of a parent while pregnant on the outcomes--both short- and long-run--of the children.

We find that maternal bereavement has small but statistically significant adverse effects on birth outcomes, and these effects are larger for boys than for girls. The effects on birth outcomes appear to be driven by deaths due to cardiovascular causes, suggesting that sudden

\footnotetext{
${ }^{29}$ We have also looked at whether there is an effect of cardiovascular deaths on later outcomes but found no significant effects on educational outcomes, cognitive scores, or labor market variables.
} 
deaths due to heart attacks may be more difficult to deal with than deaths due to more persistent causes (such as cancer). However, there is no evidence of any adverse effects on any of our later outcomes including cognitive test scores, educational attainment, and earnings. This suggests that, even though there may be measurable effects on birth outcomes, acute psychological stressors during pregnancy have limited adverse consequences on the child's success in education and the labor market.

One remaining issue is the mechanism through which bereavement affects birth outcomes. While the process may by purely physiological and be related to the body's natural responses to stress and grief, there may also be behavioral responses of the mother that affect the fetus. One such possibility is that stress increases the likelihood or level of maternal smoking. We have information on smoking behavior of mothers from 1998 onwards and we have used it to see whether bereavement affects smoking. We found no evidence of any effect. This suggests that behavioral responses may not be an important part of the story but more research with more detailed data will be required to verify this conclusion. 


\section{References}

Aizer, Anna, Laura Stroud and Stephen Buka. 2012. "Maternal Stress and Child Outcomes: Evidence from Siblings" NBER Working Paper No. 18422, September.

Almond, Douglas J. 2006. "Is the 1918 Influenza Pandemic Over? Long-Term Effects of In Utero Influenza Exposure in the Post-1940 U.S. Population." Journal of Political Economy, 114(4): 672-712.

Almond, Douglas J. and Janet Currie. 2010. Human Capital Development Before Age Five. In Handbook of Labor Economics.

Almond, Douglas J., Lena Edlund, and Marten Palme. 2009. "Chernobyl's Subclinical Legacy: Prenatal Exposure to Radioactive Fallout and School Outcomes in Sweden." The Quarterly Journal of Economics 124: 1729-1772.

Almond, D., Lena Edlund, Hongbin Li, and Junsen Zhang. 2010. "Long-Term Effects of the 1959-61 China Famine: Mainland China and Hong Kong." In The Economic Consequences of Demographic Change in East Asia, NBER-EASE Vol. 19, ed. T. Ito and A. Rose: 321-350. Chicago: University of Chicago Press.

Berkowitz, G.S., Wolff, M.S., Janevic, T.M., Holzman, I.R., Yehuda, P., Landrigan, P.J. 2003. "The World Trade Center disaster and intrauterine growth restriction." Journal of the American Medical Association 290: 595-596.

Black, Sandra E., Aline Bütikofer, Paul J. Devereux, Kjell G. Salvanes. 2013. "This Is Only a Test? Long-Run Impacts of Prenatal Exposure to Radioactive Downfall." NBER Working Paper 18987.

Black, Sandra, Paul J. Devereux, and Kjell G. Salvanes. 2007. "From the cradle to the labor market? The effect of birth weight on adult outcomes." Quarterly Journal of Economics, 122: 409-439.

Bruckner Tim A., Gerard J. van den Berg, Kirk R. Smith, Ralph A. Catalano. 2014. “Ambient Temperature During Gestation and Cold-Related Adult Mortality in a Swedish Cohort, 1915 to 2002" IZA DP No. 7986

Camacho, Adriana. 2008. "Stress and Birth Weight: Evidence from Terrorist Attacks." The American Economic Review Papers and Proceedings, Vol. 98(2): 511-515.

Catalano, Ralph and Terry Hartig. 2001. "Communal Bereavement and the Incidence of Very Low Birthweight in Sweden." Journal of Health and Social Behavior, 42(4): 333-341.

Cronbach, L.J. 1964. Essentials of Psychological Testing, 2nd Edition, London, UK: Harper and Row. 
Currie, Janet. 2011. "Inequality at Birth: Some Causes and Consequences." American Economic Review, 101(3): 1-22.

Currie Janet, Matthew J. Neidell, and Johannes F. Schmieder. 2009. "Air Pollution and Infant Health: Lessons from New Jersey.” Journal of Health Economics, 28(3): 688-703.

Currie, Janet and Maya Rossin-Slater. 2013. "Weathering the Storm: Hurricanes and Birth Outcomes. Journal of Health Economics, 32(3): 487-503.

Eide, Martha G., Nina Øyen, Rolv Skjærven, Stein Tore Nilsen, Tor Bjerkedal and Grethe S. Tell. 2005. "Size at Birth and Gestational Age as Predictors of Adult Height and Weight." Epidemiology, XVI: 175-181.

Eriksson, JG, G. Kajantie, C. Osmond, K. Thornburg, and D J. Barker. 2010. "Boys Live Dangerously in the Womb." American Journal of Human Biology, 22 (3): 330-335.

Fertig, Angela R. and Tara Watson. 2009. "Minimum Drinking Age Laws and Infant Health Outcomes." Journal of Health Economics, 28(3): 737-747.

Glynn, Laura M., Pathik D. Wadha, Christine Dunkel-Schetter, Aleksandra Chicz-Demet, and Curt A. Sandman. 2001. "When Stress Happens Matters: Effects of Earthquake Timing on Stress Responsivity in Pregnancy." American Journal of Obstetrics and Gynecology, 184(4): 637-642.

Hobel C, Culhane J. 2003. "The Role of psychosocial and nutritional stress on poor pregnancy outcome." Journal of Nutrition, 133(5 Suppl 2):1709S-1717S.

Kelly, Elaine. 2011. "The Scourge of Asian Flu: in utero Exposure to Pandemic Influenza and the Development of a Cohort of British Children." Journal of Human Resources, 46(4): 669-694.

Lauderdale, Diane S. 2006. "Birth Outcomes for Arabic-Named Women in California Before and After September 11." Demography, 43(3): 185-201.

Li Jiong, Jorn Olsen, Mogens Vestergaard, Carsten Olsen, Jennifer L. Baker, and Thorkild I. A. Sorensen. 2010. "Prenatal stress exposure related to maternal bereavement and risk of childhood overweight." PLOS ONE 5:e11896.

Møen, J., K.G. Salvanes, and E.Ø. Sørensen. 2003. "Documentation of the Linked EmpoyerEmployee Data Base at the Norwegian School of Economics." Mimeo, The Norwegian School of Economics and Business Administration.

Scholte, Robert S., Gerard J. van den Berg, and Maarten Lindeboom, 2012. "The Long-Run Effects of Gestation During the Dutch Hunger Winter Famine on Labor Market and Hospitalization Outcomes." IZA Working Paper \#6307.

Simeonova, Emilia. 2011. "Out of Sight, Out of Mind? Natural Disasters and Pregnancy Outcomes in the USA," CESifo Economic Studies, 57(3): 403-431. 
Strauss, John and Duncan Thomas. 1998. "Health, Nutrition, and Economic Development." Journal of Economic Literature, XXXVI: 766-817.

Sundet, J.M., D.G. Barlaug, and T.M. Torjussen. 2004. "The End of the Flynn Effect? A Study of Secular Trends in Mean Intelligence Test Scores of Norwegian Conscripts During Half a Century." Intelligence , XXXII: 349-362.

Sundet, J.M., K. Tambs, J.R. Harris, P. Magnus, and T.M. Torjussen. 2005. "Resolving the Genetic and Environmental Sources of the Correlation Between Height and Intelligence: A Study of Nearly 2600 Norwegian Male Twin Pairs," Twin Research and Human Genetics, VII: 1-5.

Thrane, V.C. 1977. “Evneprøving av Utskrivingspliktige i Norge 1950-53,” Arbeidsrapport nr. 26, INAS.

Torche, Florencia. 2011. "The Effect of Maternal Stress on Birth Outcomes: Exploiting a Natural Experiment." Demography, 48(4): 1473-1491. 
Table 1: Descriptive Statistics for Full Sample and Analysis Sample

\begin{tabular}{|c|c|c|c|c|c|c|}
\hline & \multicolumn{3}{|c|}{ Full Sample } & \multicolumn{3}{|c|}{ Analysis Sample } \\
\hline & count & mean & $\mathrm{Sd}$ & count & mean & $\mathrm{sd}$ \\
\hline Birth weight & 1096597 & 3585.49 & 567.50 & 784385 & 3606.49 & 557.45 \\
\hline Log birth weight $(* 10)$ & 1096597 & 81.70 & 1.81 & 784385 & 81.77 & 1.75 \\
\hline Fetal growth rate & 1096597 & 90.23 & 12.99 & 784385 & 90.75 & 12.80 \\
\hline Weeks gestation & 1097918 & 39.65 & 1.93 & 785316 & 39.67 & 1.88 \\
\hline Height (birth length) & 1061691 & 50.36 & 2.46 & 759988 & 50.43 & 2.40 \\
\hline 5 minute APGAR & 1014128 & 9.33 & 0.85 & 732943 & 9.34 & 0.82 \\
\hline C-Section & 1097918 & 0.12 & 0.33 & 785316 & 0.11 & 0.32 \\
\hline Neo-natal Ward & 1064850 & 0.04 & 0.20 & 759635 & 0.04 & 0.19 \\
\hline Education (2010) & 219624 & 13.25 & 2.52 & 142260 & 13.48 & 2.51 \\
\hline Education $\geq 12(2010)$ & 331113 & 0.83 & 0.38 & 223253 & 0.85 & 0.36 \\
\hline Full time $(2010)$ & 240066 & 0.60 & 0.49 & 156135 & 0.59 & 0.49 \\
\hline Log(earnings) & 221683 & 12.61 & 0.82 & 144038 & 12.61 & 0.84 \\
\hline Log(earnings) full time workers & 142853 & 12.92 & 0.44 & 92609 & 12.93 & 0.45 \\
\hline IQ score at 18 & 188189 & 5.30 & 1.74 & 130013 & 5.42 & 1.73 \\
\hline Height at 18 & 204453 & 180.45 & 6.56 & 140923 & 180.64 & 6.56 \\
\hline BMI at 18 & 204251 & 22.90 & 3.77 & 140780 & 22.80 & 3.65 \\
\hline Education of Mother & 1097918 & 12.91 & 2.71 & 785316 & 13.19 & 2.69 \\
\hline Education of Father & 1097918 & 12.71 & 2.78 & 785316 & 12.99 & 2.80 \\
\hline Age of mother at birth & 1097918 & 29.96 & 3.81 & 785316 & 30.30 & 3.80 \\
\hline Month of Birth & 1097918 & 6.38 & 3.37 & 785316 & 6.36 & 3.36 \\
\hline Year of Birth & 1097918 & 1993.98 & 10.01 & 785316 & 1994.18 & 9.54 \\
\hline Birth Order & 1097918 & 2.05 & 1.00 & 785316 & 2.10 & 1.04 \\
\hline Female & 1097918 & 0.49 & 0.50 & 785316 & 0.48 & 0.50 \\
\hline Death during pregnancy & 1097918 & 0.01 & 0.11 & 785316 & 0.01 & 0.11 \\
\hline Death in window & 1097918 & 0.04 & 0.20 & 785316 & 0.04 & 0.20 \\
\hline
\end{tabular}

The analysis sample includes all women who have at least two births during the sample period. 
Table 2

Effect of a Death during pregnancy on various child outcomes: OLS and IV Estimates

\begin{tabular}{|c|c|c|c|c|c|c|c|c|}
\hline & $\begin{array}{c}\text { (1) } \\
\text { Birth weight }\end{array}$ & $\begin{array}{c}(2) \\
\text { Log (Birth } \\
\text { weight) }\end{array}$ & $\begin{array}{c}\text { (3) } \\
\text { Fetal Growth }\end{array}$ & $\begin{array}{c}(4) \\
\text { Weeks } \\
\text { gestation }\end{array}$ & $\begin{array}{l}(5) \\
\text { Height }\end{array}$ & $\begin{array}{c}(6) \\
5 \text { minute } \\
\text { APGAR }\end{array}$ & $\begin{array}{c}(7) \\
\text { C-Section }\end{array}$ & $\begin{array}{c}(8) \\
\text { Neonatal } \\
\text { Ward }\end{array}$ \\
\hline \multicolumn{9}{|l|}{ "Naïve" OLS } \\
\hline Death in utero & $\begin{array}{l}-6.523 \\
(5.773)\end{array}$ & $\begin{array}{l}-0.012 \\
(0.018)\end{array}$ & $\begin{array}{l}-0.202 \\
(0.132)\end{array}$ & $\begin{array}{c}0.020 \\
(0.019)\end{array}$ & $\begin{array}{c}0.012 \\
(0.025)\end{array}$ & $\begin{array}{l}-0.006 \\
(0.009)\end{array}$ & $\begin{array}{c}0.002 \\
(0.003)\end{array}$ & $\begin{array}{c}0.000 \\
(0.002)\end{array}$ \\
\hline \multicolumn{9}{|l|}{ Reduced Form } \\
\hline Death in utero & $\begin{array}{c}-21.835^{* *} \\
(5.997) \\
\end{array}$ & $\begin{array}{l}-0.070^{* *} \\
(0.019)\end{array}$ & $\begin{array}{c}-0.392^{* *} \\
(0.136)\end{array}$ & $\begin{array}{c}-0.087^{* *} \\
(0.021)\end{array}$ & $\begin{array}{l}-0.054^{* *} \\
(0.026)\end{array}$ & $\begin{array}{l}-0.010 \\
(0.009)\end{array}$ & $\begin{array}{l}0.007^{* *} \\
(0.003)\end{array}$ & $\begin{array}{c}0.003 \\
(0.002)\end{array}$ \\
\hline \multicolumn{9}{|l|}{ IV } \\
\hline Death in utero & $\begin{array}{c}-22.172^{* *} \\
(6.095)\end{array}$ & $\begin{array}{l}-0.071^{* *} \\
(0.020)\end{array}$ & $\begin{array}{l}-0.398^{* *} \\
(0.139)\end{array}$ & $\begin{array}{c}-0.089^{* *} \\
(0.021)\end{array}$ & $\begin{array}{l}-0.055^{* *} \\
(0.027)\end{array}$ & $\begin{array}{l}-0.010 \\
(0.009)\end{array}$ & $\begin{array}{l}0.007^{* *} \\
(0.004)\end{array}$ & $\begin{array}{c}0.003 \\
(0.002)\end{array}$ \\
\hline \multicolumn{9}{|l|}{ IV FE } \\
\hline Death in utero & $\begin{array}{c}-16.109^{* *} \\
(5.643)\end{array}$ & $\begin{array}{c}-0.049^{* *} \\
(0.019)\end{array}$ & $\begin{array}{l}-0.282^{* *} \\
(0.128)\end{array}$ & $\begin{array}{l}-0.071^{* *} \\
(0.022)\end{array}$ & $\begin{array}{l}-0.025 \\
(0.027)\end{array}$ & $\begin{array}{c}-0.025^{* *} \\
(0.012)\end{array}$ & $\begin{array}{l}0.010^{* *} \\
(0.003)\end{array}$ & $\begin{array}{l}-0.001 \\
(0.003)\end{array}$ \\
\hline \multicolumn{9}{|l|}{ IV Window } \\
\hline Death in utero & $\begin{array}{c}-17.463^{* *} \\
(7.136)\end{array}$ & $\begin{array}{l}-0.055^{* *} \\
(0.023)\end{array}$ & $\begin{array}{l}-0.295^{*} \\
(0.162)\end{array}$ & $\begin{array}{l}-0.081^{* *} \\
(0.025)\end{array}$ & $\begin{array}{l}-0.049 \\
(0.031)\end{array}$ & $\begin{array}{c}-0.014 \\
(0.011)\end{array}$ & $\begin{array}{c}0.006 \\
(0.004)\end{array}$ & $\begin{array}{c}0.001 \\
(0.002)\end{array}$ \\
\hline Death in window & $\begin{array}{l}-4.816 \\
(3.763) \\
\end{array}$ & $\begin{array}{l}-0.017 \\
(0.012)\end{array}$ & $\begin{array}{l}-0.105 \\
(0.086)\end{array}$ & $\begin{array}{c}-0.008 \\
(0.013)\end{array}$ & $\begin{array}{l}-0.006 \\
(0.016)\end{array}$ & $\begin{array}{c}0.004 \\
(0.006)\end{array}$ & $\begin{array}{c}0.001 \\
(0.002)\end{array}$ & $\begin{array}{c}0.002 \\
(0.001)\end{array}$ \\
\hline \multicolumn{9}{|l|}{ IV Window FE } \\
\hline Death in utero & $\begin{array}{c}-23.285^{* *} \\
(6.669)\end{array}$ & $\begin{array}{c}-0.072^{* *} \\
(0.022)\end{array}$ & $\begin{array}{c}-0.429^{* *} \\
(0.151)\end{array}$ & $\begin{array}{c}-0.089^{* *} \\
(0.026)\end{array}$ & $\begin{array}{l}-0.084^{* *} \\
(0.032)\end{array}$ & $\begin{array}{c}-0.029^{* *} \\
(0.014)\end{array}$ & $\begin{array}{l}0.013^{* *} \\
(0.004)\end{array}$ & $\begin{array}{c}-0.002 \\
(0.003)\end{array}$ \\
\hline Death in window & $\begin{array}{l}7.484^{* *} \\
(3.618)\end{array}$ & $\begin{array}{l}0.024^{* *} \\
(0.012)\end{array}$ & $\begin{array}{c}0.153^{*} \\
(0.082)\end{array}$ & $\begin{array}{c}0.019 \\
(0.014)\end{array}$ & $\begin{array}{l}0.062^{* *} \\
(0.018)\end{array}$ & $\begin{array}{c}0.004 \\
(0.008)\end{array}$ & $\begin{array}{l}-0.003 \\
(0.002)\end{array}$ & $\begin{array}{c}0.001 \\
(0.002)\end{array}$ \\
\hline $\mathrm{N}$ & 784385 & 784385 & 784385 & 785316 & 759988 & 732943 & 785316 & 759635 \\
\hline
\end{tabular}


The sample includes all women who have at least two births during the sample period.

"Naïve" OLS, Reduced Form, and IV specifications include controls for age of mother, maternal and paternal education, gender of child, birth order of child, and year of birth by month of birth dummies.

IV FE and IV Window FE specifications include mother fixed effects and exclude maternal age and education.

IV Window and IV Window FE specifications include a control for whether there is a grandparent death in the window around pregnancy.

The window around birth includes the year prior to conception, the 9 months post-conception, and the year subsequent to that.

All the IV specifications instrument the indicator variable for a death during pregnancy with an indicator variable for a death within 9 months of the conception date.

Coefficients on $\log ($ birth weight) are multiplied by 10 . 
Table 3

Mother Fixed Effects Estimates (IV estimates)

By Cause of Death

\begin{tabular}{|c|c|c|c|c|c|c|c|c|}
\hline & $\begin{array}{c}\text { (1) } \\
\text { Birth weight }\end{array}$ & $\begin{array}{c}(2) \\
\text { Log (Birth } \\
\text { weight) }\end{array}$ & $\begin{array}{c}(3) \\
\text { Fetal } \\
\text { Growth }\end{array}$ & $\begin{array}{c}(4) \\
\text { Weeks } \\
\text { gestation }\end{array}$ & $\begin{array}{c}(5) \\
\text { Height }\end{array}$ & $\begin{array}{c}(6) \\
5 \text { minute } \\
\text { APGAR }\end{array}$ & $\begin{array}{c}(7) \\
\text { C-Section }\end{array}$ & $\begin{array}{c}(8) \\
\text { Neonatal } \\
\text { Ward }\end{array}$ \\
\hline Cardiovascular & $\begin{array}{l}-32.544^{* *} \\
(10.589)\end{array}$ & $\begin{array}{l}-0.112^{* *} \\
(0.035)\end{array}$ & $\begin{array}{l}-0.533^{* *} \\
(0.240)\end{array}$ & $\begin{array}{l}-0.160^{* *} \\
(0.042)\end{array}$ & $\begin{array}{l}-0.132^{* *} \\
(0.051)\end{array}$ & $\begin{array}{l}-0.057^{* *} \\
(0.023)\end{array}$ & $\begin{array}{l}0.012^{* *} \\
(0.006)\end{array}$ & $\begin{array}{c}0.004 \\
(0.005)\end{array}$ \\
\hline Cancer & $\begin{array}{l}-21.198 \\
(14.775)\end{array}$ & $\begin{array}{l}-0.053 \\
(0.049)\end{array}$ & $\begin{array}{l}-0.450 \\
(0.335)\end{array}$ & $\begin{array}{l}-0.053 \\
(0.059)\end{array}$ & $\begin{array}{l}-0.159^{* *} \\
(0.072)\end{array}$ & $\begin{array}{l}-0.035 \\
(0.032)\end{array}$ & $\begin{array}{c}0.001 \\
(0.008)\end{array}$ & $\begin{array}{l}-0.000 \\
(0.007)\end{array}$ \\
\hline Other cause & $\begin{array}{l}-16.314 \\
(10.501)\end{array}$ & $\begin{array}{l}-0.044 \\
(0.035)\end{array}$ & $\begin{array}{l}-0.321 \\
(0.238)\end{array}$ & $\begin{array}{l}-0.048 \\
(0.042)\end{array}$ & $\begin{array}{l}-0.002 \\
(0.051)\end{array}$ & $\begin{array}{l}-0.002 \\
(0.022)\end{array}$ & $\begin{array}{l}0.019^{* *} \\
(0.006)\end{array}$ & $\begin{array}{l}-0.009^{*} \\
(0.005)\end{array}$ \\
\hline $\begin{array}{l}\text { Death in window- } \\
\text { Cardio }\end{array}$ & $\begin{array}{c}4.682 \\
(5.712)\end{array}$ & $\begin{array}{c}0.014 \\
(0.019)\end{array}$ & $\begin{array}{c}0.020 \\
(0.130)\end{array}$ & $\begin{array}{l}0.046^{* *} \\
(0.023)\end{array}$ & $\begin{array}{c}0.045 \\
(0.028)\end{array}$ & $\begin{array}{l}0.027^{* *} \\
(0.012)\end{array}$ & $\begin{array}{l}-0.002 \\
(0.003)\end{array}$ & $\begin{array}{l}-0.000 \\
(0.003)\end{array}$ \\
\hline $\begin{array}{l}\text { Death in window- } \\
\text { Cancer }\end{array}$ & $\begin{array}{l}11.273 \\
(7.798)\end{array}$ & $\begin{array}{c}0.038 \\
(0.026)\end{array}$ & $\begin{array}{l}0.320^{*} \\
(0.177)\end{array}$ & $\begin{array}{l}-0.007 \\
(0.031)\end{array}$ & $\begin{array}{l}0.096^{* *} \\
(0.038)\end{array}$ & $\begin{array}{l}-0.005 \\
(0.017)\end{array}$ & $\begin{array}{l}-0.001 \\
(0.004)\end{array}$ & $\begin{array}{c}0.001 \\
(0.004)\end{array}$ \\
\hline $\begin{array}{l}\text { Death in window- } \\
\text { Other }\end{array}$ & $\begin{array}{l}9.623^{*} \\
(5.660)\end{array}$ & $\begin{array}{c}0.029 \\
(0.019)\end{array}$ & $\begin{array}{c}0.214^{*} \\
(0.128)\end{array}$ & $\begin{array}{c}0.014 \\
(0.022)\end{array}$ & $\begin{array}{l}0.065^{* *} \\
(0.028)\end{array}$ & $\begin{array}{l}-0.012 \\
(0.012)\end{array}$ & $\begin{array}{l}-0.006^{*} \\
(0.003)\end{array}$ & $\begin{array}{c}0.003 \\
(0.003)\end{array}$ \\
\hline$N$ & 784385 & 784385 & 784385 & 785316 & 759988 & 732943 & 785316 & 759635 \\
\hline \multicolumn{9}{|c|}{$\begin{array}{l}\text { Standard errors in parentheses } \\
{ }^{*} p<0.10,{ }^{* *} p<0.05\end{array}$} \\
\hline
\end{tabular}


Table 4

Effect of a death during pregnancy on various child outcomes

Mother fixed effects estimates by trimester

Instrumental Variables Estimates

\begin{tabular}{|c|c|c|c|c|c|c|c|c|}
\hline & $\begin{array}{c}(1) \\
\text { Birth } \\
\text { weight }\end{array}$ & $\begin{array}{c}(2) \\
\text { Log (Birth } \\
\text { weight) }\end{array}$ & $\begin{array}{c}(3) \\
\text { Fetal } \\
\text { Growth }\end{array}$ & $\begin{array}{c}(4) \\
\text { Weeks } \\
\text { gestation }\end{array}$ & $\begin{array}{l}(5) \\
\text { Height }\end{array}$ & $\begin{array}{c}(6) \\
5 \text { minute } \\
\text { APGAR }\end{array}$ & $\begin{array}{c}(7) \\
\text { C-Section }\end{array}$ & $\begin{array}{c}(8) \\
\text { Neonatal } \\
\text { Ward }\end{array}$ \\
\hline $1^{\text {st }}$ Trimester & $\begin{array}{l}-20.752^{* *} \\
(10.373)\end{array}$ & $\begin{array}{l}-0.063^{*} \\
(0.034)\end{array}$ & $\begin{array}{l}-0.249 \\
(0.235)\end{array}$ & $\begin{array}{l}-0.119^{* *} \\
(0.041)\end{array}$ & $\begin{array}{l}-0.112^{* *} \\
(0.051)\end{array}$ & $\begin{array}{l}-0.037^{*} \\
(0.022)\end{array}$ & $\begin{array}{l}0.014^{* *} \\
(0.006)\end{array}$ & $\begin{array}{l}-0.004 \\
(0.005)\end{array}$ \\
\hline $2^{\text {nd }}$ Trimester & $\begin{array}{c}-23.248^{* *} \\
(10.249)\end{array}$ & $\begin{array}{c}-0.070^{* *} \\
(0.034)\end{array}$ & $\begin{array}{c}-0.567^{* *} \\
(0.232)\end{array}$ & $\begin{array}{c}-0.043 \\
(0.041)\end{array}$ & $\begin{array}{l}-0.058 \\
(0.050)\end{array}$ & $\begin{array}{l}-0.028 \\
(0.022)\end{array}$ & $\begin{array}{l}0.013^{* *} \\
(0.006)\end{array}$ & $\begin{array}{c}0.003 \\
(0.005)\end{array}$ \\
\hline $3^{\text {rd }}$ Trimester & $\begin{array}{c}-25.888^{* *} \\
(10.450)\end{array}$ & $\begin{array}{l}-0.082^{* *} \\
(0.035)\end{array}$ & $\begin{array}{c}-0.469^{* *} \\
(0.237)\end{array}$ & $\begin{array}{c}-0.107^{* *} \\
(0.041)\end{array}$ & $\begin{array}{l}-0.083 \\
(0.051)\end{array}$ & $\begin{array}{l}-0.023 \\
(0.022)\end{array}$ & $\begin{array}{c}0.010^{*} \\
(0.006)\end{array}$ & $\begin{array}{c}-0.004 \\
(0.005)\end{array}$ \\
\hline Death in window & $\begin{array}{l}7.536^{* *} \\
(3.618)\end{array}$ & $\begin{array}{l}0.024^{* *} \\
(0.012)\end{array}$ & $\begin{array}{c}0.154^{*} \\
(0.082)\end{array}$ & $\begin{array}{c}0.019 \\
(0.014)\end{array}$ & $\begin{array}{l}0.062^{* *} \\
(0.018)\end{array}$ & $\begin{array}{c}0.004 \\
(0.008)\end{array}$ & $\begin{array}{c}-0.003 \\
(0.002)\end{array}$ & $\begin{array}{c}0.001 \\
(0.002)\end{array}$ \\
\hline$N$ & 784385 & 784385 & 784385 & 785316 & 759988 & 732943 & 785316 & 759635 \\
\hline \multicolumn{9}{|c|}{$\begin{array}{l}\text { Standard errors in parentheses } \\
{ }^{*} p<0.10, \quad p<0.05 \\
\text { The sample includes all women who have at least two births during the sample period. } \\
\text { All specifications include controls for age of mother, paternal education, gender of child, birth order of child, and year of birth by month of birth dummies. } \\
\text { All regressions include mother fixed effects and instrument the indicator variables for a death during each trimester with indicator variables for a death within } 3 \\
\text { months of the conception date, between } 4 \text { months and } 6 \text { months after the conception date, and between } 7 \text { months and } 9 \text { months after the conception date. } \\
\text { Coefficients on log(birth weight) are multiplied by } 10 \text {. }\end{array}$} \\
\hline
\end{tabular}


Table 5

Effect of a death during pregnancy on various child outcomes

By Grandparent Gender

Mother fixed effects Instrumental Variables Estimates

\begin{tabular}{|c|c|c|c|c|c|c|c|c|}
\hline & $\begin{array}{c}\text { (1) } \\
\text { Birth weight }\end{array}$ & $\begin{array}{c}\text { (2) } \\
\text { Log (Birth } \\
\text { weight) }\end{array}$ & $\begin{array}{c}(3) \\
\text { Fetal } \\
\text { Growth }\end{array}$ & $\begin{array}{c}(4) \\
\text { Weeks } \\
\text { gestation }\end{array}$ & $\begin{array}{c}(5) \\
\text { Height }\end{array}$ & $\begin{array}{c}(6) \\
5 \text { minute } \\
\text { APGAR }\end{array}$ & $\begin{array}{c}(7) \\
\text { C-Section }\end{array}$ & $\begin{array}{c}(8) \\
\text { Neonatal } \\
\text { Ward }\end{array}$ \\
\hline $\begin{array}{l}\text { Death of } \\
\text { grandmother } \\
\text { in utero }\end{array}$ & $\begin{array}{c}-9.175 \\
(12.360)\end{array}$ & $\begin{array}{c}-0.020 \\
(0.041)\end{array}$ & $\begin{array}{l}-0.185 \\
(0.280)\end{array}$ & $\begin{array}{l}-0.019 \\
(0.049)\end{array}$ & $\begin{array}{l}-0.037 \\
(0.060)\end{array}$ & $\begin{array}{l}-0.007 \\
(0.026)\end{array}$ & $\begin{array}{l}0.019^{* *} \\
(0.007)\end{array}$ & $\begin{array}{l}-0.002 \\
(0.006)\end{array}$ \\
\hline $\begin{array}{l}\text { Death of } \\
\text { grandfather } \\
\text { in utero }\end{array}$ & $\begin{array}{c}-30.169^{* *} \\
(7.870)\end{array}$ & $\begin{array}{l}-0.095^{* *} \\
(0.026)\end{array}$ & $\begin{array}{l}-0.545^{* *} \\
(0.178)\end{array}$ & $\begin{array}{l}-0.122^{* *} \\
(0.031)\end{array}$ & $\begin{array}{l}-0.109^{* *} \\
(0.038)\end{array}$ & $\begin{array}{l}-0.038^{* *} \\
(0.017)\end{array}$ & $\begin{array}{l}0.010^{* *} \\
(0.004)\end{array}$ & $\begin{array}{l}-0.002 \\
(0.004)\end{array}$ \\
\hline $\begin{array}{l}\text { Death of } \\
\text { grandmother in } \\
\text { window }\end{array}$ & $\begin{array}{l}-0.490 \\
(6.528)\end{array}$ & $\begin{array}{l}-0.007 \\
(0.022)\end{array}$ & $\begin{array}{c}0.052 \\
(0.148)\end{array}$ & $\begin{array}{l}-0.036 \\
(0.026)\end{array}$ & $\begin{array}{l}0.060^{*} \\
(0.032)\end{array}$ & $\begin{array}{l}-0.016 \\
(0.014)\end{array}$ & $\begin{array}{l}-0.006 \\
(0.004)\end{array}$ & $\begin{array}{c}0.001 \\
(0.003)\end{array}$ \\
\hline $\begin{array}{l}\text { Death of } \\
\text { grandfather in } \\
\text { window }\end{array}$ & $\begin{array}{l}11.507^{* *} \\
(4.214)\end{array}$ & $\begin{array}{l}0.037^{* *} \\
(0.014)\end{array}$ & $\begin{array}{l}0.203^{* *} \\
(0.096)\end{array}$ & $\begin{array}{l}0.045^{* *} \\
(0.017)\end{array}$ & $\begin{array}{l}0.067^{* *} \\
(0.021)\end{array}$ & $\begin{array}{c}0.012 \\
(0.009)\end{array}$ & $\begin{array}{l}-0.002 \\
(0.002)\end{array}$ & $\begin{array}{c}0.001 \\
(0.002)\end{array}$ \\
\hline$N$ & 784385 & 784385 & 784385 & 785316 & 759988 & 732943 & 785316 & 759635 \\
\hline \multicolumn{9}{|c|}{$\begin{array}{l}\text { Standard errors in parentheses } \\
{ }^{*} p<0.10,{ }^{* *} p<0.05\end{array}$} \\
\hline
\end{tabular}


Table 6

Effect of a death during pregnancy on various child outcomes

By Whether Birth and Death are in the Same County

Mother fixed effects Instrumental Variables Estimates

\begin{tabular}{|c|c|c|c|c|c|c|c|c|}
\hline & $\begin{array}{l}\text { (1) } \\
\text { Birth } \\
\text { weight }\end{array}$ & $\begin{array}{l}\text { (2) } \\
\text { Log (Birth } \\
\text { weight) }\end{array}$ & $\begin{array}{l}(3) \\
\text { Fetal } \\
\text { Growth }\end{array}$ & $\begin{array}{l}(4) \\
\text { Weeks } \\
\text { gestation }\end{array}$ & $\begin{array}{l}\text { (5) } \\
\text { Height }\end{array}$ & $\begin{array}{l}(6) \\
5 \text { minute } \\
\text { APGAR }\end{array}$ & $\begin{array}{l}\text { (7) } \\
\text { C-Section }\end{array}$ & $\begin{array}{l}(8) \\
\text { Neonatal } \\
\text { Ward }\end{array}$ \\
\hline $\begin{array}{l}\text { Death in utero - } \\
\text { same county }\end{array}$ & $\begin{array}{l}-25.542^{* *} \\
(8.255)\end{array}$ & $\begin{array}{l}-0.086^{* *} \\
(0.027)\end{array}$ & $\begin{array}{l}-0.534^{* *} \\
(0.187)\end{array}$ & $\begin{array}{l}-0.075^{* *} \\
(0.033)\end{array}$ & $\begin{array}{l}-0.106^{* *} \\
(0.040)\end{array}$ & $\begin{array}{l}-0.040^{* *} \\
(0.018)\end{array}$ & $\begin{array}{l}0.012^{* *} \\
(0.005)\end{array}$ & $\begin{array}{l}-0.004 \\
(0.004)\end{array}$ \\
\hline $\begin{array}{l}\text { Death in utero - } \\
\text { different county }\end{array}$ & $\begin{array}{l}-20.379^{*} \\
(11.424)\end{array}$ & $\begin{array}{l}-0.050 \\
(0.038)\end{array}$ & $\begin{array}{l}-0.246 \\
(0.259)\end{array}$ & $\begin{array}{l}-0.127^{* *} \\
(0.045)\end{array}$ & $\begin{array}{l}-0.031 \\
(0.056)\end{array}$ & $\begin{array}{l}-0.012 \\
(0.024)\end{array}$ & $\begin{array}{l}0.015^{* *} \\
(0.006)\end{array}$ & $\begin{array}{l}0.002 \\
(0.005)\end{array}$ \\
\hline $\begin{array}{l}\text { Death in window } \\
\text { - same county }\end{array}$ & $\begin{array}{l}6.779 \\
(4.450)\end{array}$ & $\begin{array}{l}0.021 \\
(0.015)\end{array}$ & $\begin{array}{l}0.165 \\
(0.101)\end{array}$ & $\begin{array}{l}0.002 \\
(0.018)\end{array}$ & $\begin{array}{l}0.056^{* *} \\
(0.022)\end{array}$ & $\begin{array}{l}0.008 \\
(0.009)\end{array}$ & $\begin{array}{l}-0.002 \\
(0.003)\end{array}$ & $\begin{array}{l}0.002 \\
(0.002)\end{array}$ \\
\hline $\begin{array}{l}\text { Death in window } \\
\text { - different county }\end{array}$ & $\begin{array}{l}7.573 \\
(6.182)\end{array}$ & $\begin{array}{l}0.024 \\
(0.020)\end{array}$ & $\begin{array}{l}0.108 \\
(0.140)\end{array}$ & $\begin{array}{l}0.044^{*} \\
(0.025)\end{array}$ & $\begin{array}{l}0.064^{* *} \\
(0.030)\end{array}$ & $\begin{array}{l}-0.005 \\
(0.013)\end{array}$ & $\begin{array}{l}-0.005 \\
(0.003)\end{array}$ & $\begin{array}{l}0.001 \\
(0.003)\end{array}$ \\
\hline$N$ & 784385 & 784385 & 784385 & 785316 & 759988 & 732943 & 785316 & 759635 \\
\hline \multicolumn{9}{|c|}{$\begin{array}{l}\text { Standard errors in parentheses } \\
{ }^{*} p<0.10,{ }^{* *} p<0.05 \\
\text { The sample includes all women who have at least two births during the sample period. } \\
\text { All specifications include controls for age of mother, paternal education, gender of child, birth order of child, and year of birth by month of birth dummies. } \\
\text { All regressions include mother fixed effects and instrument the indicator variables for each type of death during pregnancy with an indicator variable for a death } \\
\text { of that type within } 9 \text { months of the conception date. } \\
\text { Coefficients on } \log (\text { birth weight) are multiplied by } 10 .\end{array}$} \\
\hline
\end{tabular}


Table 7

Effect of a death during pregnancy on various child outcomes (IV estimates)

Mother fixed effects estimates

Interaction with Male Child

\begin{tabular}{|c|c|c|c|c|c|c|c|c|}
\hline & $\begin{array}{c}\text { (1) } \\
\text { Birth } \\
\text { weight }\end{array}$ & $\begin{array}{c}\text { (2) } \\
\text { Log (Birth } \\
\text { weight) }\end{array}$ & $\begin{array}{c}\text { (3) } \\
\text { Fetal } \\
\text { Growth }\end{array}$ & $\begin{array}{c}\text { (4) } \\
\text { Weeks } \\
\text { gestation }\end{array}$ & $\begin{array}{c}(5) \\
\text { Height }\end{array}$ & $\begin{array}{c}(6) \\
5 \text { minute } \\
\text { APGAR }\end{array}$ & $\begin{array}{c}(7) \\
\text { C-Section }\end{array}$ & $\begin{array}{c}(8) \\
\text { Neonatal } \\
\text { Ward }\end{array}$ \\
\hline Death in utero & $\begin{array}{l}-8.829 \\
(9.591)\end{array}$ & $\begin{array}{c}-0.023 \\
(0.032)\end{array}$ & $\begin{array}{c}-0.086 \\
(0.217)\end{array}$ & $\begin{array}{l}-0.076^{* *} \\
(0.038)\end{array}$ & $\begin{array}{c}0.014 \\
(0.047)\end{array}$ & $\begin{array}{c}-0.028 \\
(0.020)\end{array}$ & $\begin{array}{l}0.010^{*} \\
(0.005)\end{array}$ & $\begin{array}{c}-0.004 \\
(0.004)\end{array}$ \\
\hline Death in utero*male & $\begin{array}{l}-27.862^{* *} \\
(13.304)\end{array}$ & $\begin{array}{l}-0.094^{* *} \\
(0.044)\end{array}$ & $\begin{array}{l}-0.662^{* *} \\
(0.302)\end{array}$ & $\begin{array}{l}-0.026 \\
(0.053)\end{array}$ & $\begin{array}{l}-0.190^{* *} \\
(0.065)\end{array}$ & $\begin{array}{l}-0.002 \\
(0.028)\end{array}$ & $\begin{array}{c}0.006 \\
(0.007)\end{array}$ & $\begin{array}{c}0.004 \\
(0.006)\end{array}$ \\
\hline Male & $\begin{array}{c}132.936^{* *} \\
(1.223)\end{array}$ & $\begin{array}{l}0.362^{* *} \\
(0.004)\end{array}$ & $\begin{array}{l}3.345^{* *} \\
(0.028)\end{array}$ & $\begin{array}{l}-0.016^{* *} \\
(0.005)\end{array}$ & $\begin{array}{l}0.840^{* *} \\
(0.006)\end{array}$ & $\begin{array}{l}-0.064^{* *} \\
(0.003)\end{array}$ & $\begin{array}{l}0.007^{* *} \\
(0.001)\end{array}$ & $\begin{array}{l}0.009^{* *} \\
(0.001)\end{array}$ \\
\hline Death in window & $\begin{array}{c}2.267 \\
(5.092)\end{array}$ & $\begin{array}{c}0.009 \\
(0.017)\end{array}$ & $\begin{array}{c}0.018 \\
(0.115)\end{array}$ & $\begin{array}{c}0.026 \\
(0.020)\end{array}$ & $\begin{array}{l}0.042^{*} \\
(0.025)\end{array}$ & $\begin{array}{l}-0.005 \\
(0.011)\end{array}$ & $\begin{array}{l}-0.003 \\
(0.003)\end{array}$ & $\begin{array}{c}0.002 \\
(0.002)\end{array}$ \\
\hline Death in window*male & $\begin{array}{r}10.061 \\
(6.925) \\
\end{array}$ & $\begin{array}{c}0.028 \\
(0.023)\end{array}$ & $\begin{array}{l}0.261^{*} \\
(0.157)\end{array}$ & $\begin{array}{l}-0.013 \\
(0.027)\end{array}$ & $\begin{array}{c}0.038 \\
(0.034)\end{array}$ & $\begin{array}{c}0.018 \\
(0.015)\end{array}$ & $\begin{array}{l}-0.001 \\
(0.004)\end{array}$ & $\begin{array}{l}-0.002 \\
(0.003)\end{array}$ \\
\hline$N$ & 784385 & 784385 & 784385 & 785316 & 759988 & 732943 & 785316 & 759635 \\
\hline \multicolumn{9}{|c|}{$\begin{array}{l}\text { Standard errors in parentheses } \\
{ }^{*} p<0.10,{ }^{* *} p<0.05 \\
\text { The sample includes all women who have at least two births during the sample period. } \\
\text { All specifications include controls for age of mother, paternal education, gender of child, birth order of child, and year of birth by month of birth dummies. } \\
\text { All regressions include mother fixed effects and instrument the indicator variable for death during pregnancy with an indicator variable for a death within } 9 \\
\text { months of the conception date. The interaction of death in utero with male is also instrumented by the interaction of male with the instrument. } \\
\text { Coefficients on log(birth weight) are multiplied by } 10 \text {. } \\
\text { The window around birth includes the year prior to conception, the } 9 \text { months post-conception, and the year subsequent to that. }\end{array}$} \\
\hline
\end{tabular}


Table 8

Effect of a death during pregnancy on various child outcomes Interactions with birth year and with maternal education Mother fixed effects Instrumental Variables Estimates

\begin{tabular}{|c|c|c|c|c|c|c|c|c|}
\hline & $\begin{array}{c}\text { Birth } \\
\text { weight }\end{array}$ & $\begin{array}{l}\text { Log (Birth } \\
\text { weight) }\end{array}$ & $\begin{array}{c}\text { Fetal } \\
\text { Growth }\end{array}$ & $\begin{array}{l}\text { Weeks } \\
\text { gestation }\end{array}$ & Height & $\begin{array}{l}5 \text { minute } \\
\text { APGAR }\end{array}$ & C-Section & $\begin{array}{c}\text { Neonatal } \\
\text { Ward }\end{array}$ \\
\hline Death in utero & $\begin{array}{l}-20.048^{*} \\
(11.537)\end{array}$ & $\begin{array}{l}-0.073^{*} \\
(0.038)\end{array}$ & $\begin{array}{c}-0.141 \\
(0.262)\end{array}$ & $\begin{array}{c}-0.189^{* *} \\
(0.046)\end{array}$ & $\begin{array}{l}-0.072 \\
(0.056)\end{array}$ & $\begin{array}{l}-0.052^{*} \\
(0.028)\end{array}$ & $\begin{array}{c}0.012^{*} \\
(0.006)\end{array}$ & $\begin{array}{c}0.005 \\
(0.005)\end{array}$ \\
\hline Death*Born after 1988 & $\begin{array}{c}-4.924 \\
(14.134) \\
\end{array}$ & $\begin{array}{c}0.002 \\
(0.047) \\
\end{array}$ & $\begin{array}{l}-0.435 \\
(0.320) \\
\end{array}$ & $\begin{array}{l}0.149^{* *} \\
(0.056)\end{array}$ & $\begin{array}{l}-0.020 \\
(0.069)\end{array}$ & $\begin{array}{c}0.031 \\
(0.032) \\
\end{array}$ & $\begin{array}{c}0.001 \\
(0.008)\end{array}$ & $\begin{array}{l}-0.012^{*} \\
(0.006)\end{array}$ \\
\hline & $\begin{array}{c}\text { Birth } \\
\text { weight }\end{array}$ & $\begin{array}{l}\text { Log (Birth } \\
\text { weight) }\end{array}$ & $\begin{array}{c}\text { Fetal } \\
\text { Growth }\end{array}$ & $\begin{array}{l}\text { Weeks } \\
\text { gestation }\end{array}$ & Height & $\begin{array}{l}5 \text { minute } \\
\text { APGAR }\end{array}$ & C-Section & $\begin{array}{c}\text { Neonatal } \\
\text { Ward }\end{array}$ \\
\hline Death in utero & $\begin{array}{c}-11.712 \\
(9.186)\end{array}$ & $\begin{array}{c}-0.036 \\
(0.030)\end{array}$ & $\begin{array}{c}-0.221 \\
(0.208)\end{array}$ & $\begin{array}{c}-0.051 \\
(0.036)\end{array}$ & $\begin{array}{l}-0.043 \\
(0.045)\end{array}$ & $\begin{array}{l}-0.035^{*} \\
(0.020)\end{array}$ & $\begin{array}{l}0.012^{* *} \\
(0.005)\end{array}$ & $\begin{array}{c}-0.001 \\
(0.004)\end{array}$ \\
\hline $\begin{array}{l}\text { Death*Mother } \\
\text { education }>12\end{array}$ & $\begin{array}{l}-24.528^{*} \\
(13.362)\end{array}$ & $\begin{array}{l}-0.075^{*} \\
(0.044)\end{array}$ & $\begin{array}{l}-0.443 \\
(0.303)\end{array}$ & $\begin{array}{l}-0.080 \\
(0.053)\end{array}$ & $\begin{array}{l}-0.088 \\
(0.065)\end{array}$ & $\begin{array}{c}0.012 \\
(0.028)\end{array}$ & $\begin{array}{c}0.002 \\
(0.008)\end{array}$ & $\begin{array}{l}-0.003 \\
(0.006)\end{array}$ \\
\hline
\end{tabular}

Standard errors in parentheses

${ }^{*} p<0.10,{ }^{* *} p<0.05$

The sample includes all women who have at least two births during the sample period.

All specifications include controls for age of mother, paternal education, gender of child, birth order of child, and year of birth by month of birth dummies.

All regressions include mother fixed effects and instrument the indicator variable for death during pregnancy with an indicator variable for a death within 9 months of the conception date. The interaction of death in utero with the relevant child or mother characteristic is also instrumented by the interaction of that characteristic with the instrument.

Coefficients on $\log$ (birth weight) are multiplied by 10 .

The window around birth includes the year prior to conception, the 9 months post-conception, and the year subsequent to that.

All specifications also include a death in window dummy and its interaction with the relevant child or mother characteristic. 
Table 9

Effect of a death during pregnancy on various child outcomes - Later Outcomes

\begin{tabular}{|c|c|c|c|c|c|c|c|c|}
\hline & $\begin{array}{c}\text { (1) } \\
\text { Completed } \\
\text { Education }\end{array}$ & $\begin{array}{c}(2) \\
\text { Education } 12 \\
\text { years or } \\
\text { more }\end{array}$ & $\begin{array}{l}\text { (3) } \\
\text { Full time }\end{array}$ & $\begin{array}{c}(4) \\
\text { Log } \\
\text { (earnings) }\end{array}$ & $\begin{array}{c}(5) \\
\text { Log } \\
\text { (earnings) if } \\
\text { full time }\end{array}$ & $\begin{array}{c}(6) \\
\text { Cognitive } \\
\text { Score }\end{array}$ & $\begin{array}{c}(7) \\
\text { Height at } 18\end{array}$ & $\begin{array}{c}(8) \\
\text { BMI at } 18\end{array}$ \\
\hline \multicolumn{9}{|l|}{ OLS } \\
\hline Death in utero & $\begin{array}{c}-0.038 \\
(0.051)\end{array}$ & $\begin{array}{c}0.001 \\
(0.006)\end{array}$ & $\begin{array}{l}-0.010 \\
(0.010)\end{array}$ & $\begin{array}{c}0.000 \\
(0.017)\end{array}$ & $\begin{array}{l}-0.010 \\
(0.012)\end{array}$ & $\begin{array}{c}-0.012 \\
(0.037)\end{array}$ & $\begin{array}{c}-0.052 \\
(0.145)\end{array}$ & $\begin{array}{c}0.082 \\
(0.084)\end{array}$ \\
\hline \multicolumn{9}{|l|}{ Reduced Form } \\
\hline Death in utero & $\begin{array}{l}-0.052 \\
(0.051) \\
\end{array}$ & $\begin{array}{c}0.001 \\
(0.006) \\
\end{array}$ & $\begin{array}{l}-0.010 \\
(0.011) \\
\end{array}$ & $\begin{array}{c}0.000 \\
(0.018) \\
\end{array}$ & $\begin{array}{l}-0.009 \\
(0.012) \\
\end{array}$ & $\begin{array}{l}-0.023 \\
(0.037) \\
\end{array}$ & $\begin{array}{c}-0.079 \\
(0.147) \\
\end{array}$ & $\begin{array}{c}0.101 \\
(0.085) \\
\end{array}$ \\
\hline \multicolumn{9}{|l|}{ IV } \\
\hline Death in utero & $\begin{array}{c}-0.052 \\
(0.052) \\
\end{array}$ & $\begin{array}{c}0.001 \\
(0.006) \\
\end{array}$ & $\begin{array}{c}-0.010 \\
(0.011) \\
\end{array}$ & $\begin{array}{c}0.000 \\
(0.018) \\
\end{array}$ & $\begin{array}{c}-0.009 \\
(0.012) \\
\end{array}$ & $\begin{array}{c}-0.023 \\
(0.038) \\
\end{array}$ & $\begin{array}{c}-0.080 \\
(0.149) \\
\end{array}$ & $\begin{array}{c}0.103 \\
(0.086) \\
\end{array}$ \\
\hline \multicolumn{9}{|l|}{ IV FE } \\
\hline Death in utero & $\begin{array}{c}-0.061 \\
(0.070) \\
\end{array}$ & $\begin{array}{c}0.010 \\
(0.008) \\
\end{array}$ & $\begin{array}{c}-0.006 \\
(0.015) \\
\end{array}$ & $\begin{array}{c}0.002 \\
(0.025) \\
\end{array}$ & $\begin{array}{c}0.001 \\
(0.020) \\
\end{array}$ & $\begin{array}{c}0.022 \\
(0.063) \\
\end{array}$ & $\begin{array}{c}0.162 \\
(0.205) \\
\end{array}$ & $\begin{array}{c}0.109 \\
(0.127) \\
\end{array}$ \\
\hline \multicolumn{9}{|l|}{ IV Window } \\
\hline Death in utero & $\begin{array}{l}-0.052 \\
(0.060)\end{array}$ & $\begin{array}{c}0.000 \\
(0.008)\end{array}$ & $\begin{array}{l}-0.002 \\
(0.012)\end{array}$ & $\begin{array}{c}0.004 \\
(0.021)\end{array}$ & $\begin{array}{l}-0.003 \\
(0.014)\end{array}$ & $\begin{array}{l}-0.021 \\
(0.045)\end{array}$ & $\begin{array}{c}0.051 \\
(0.177)\end{array}$ & $\begin{array}{c}0.036 \\
(0.101)\end{array}$ \\
\hline Death in window & $\begin{array}{c}-0.001 \\
(3.763) \\
\end{array}$ & $\begin{array}{c}0.001 \\
(0.012) \\
\end{array}$ & $\begin{array}{l}-0.008 \\
(0.086) \\
\end{array}$ & $\begin{array}{l}-0.004 \\
(0.013) \\
\end{array}$ & $\begin{array}{c}-0.006 \\
(0.016) \\
\end{array}$ & $\begin{array}{l}-0.002 \\
(0.006) \\
\end{array}$ & $\begin{array}{l}-0.135 \\
(0.002)\end{array}$ & $\begin{array}{c}0.068 \\
(0.001) \\
\end{array}$ \\
\hline \multicolumn{9}{|l|}{ IV Window FE } \\
\hline Death in utero & $\begin{array}{l}-0.126 \\
(0.082)\end{array}$ & $\begin{array}{c}0.004 \\
(0.010)\end{array}$ & $\begin{array}{c}0.007 \\
(0.018)\end{array}$ & $\begin{array}{l}-0.006 \\
(0.029)\end{array}$ & $\begin{array}{l}-0.008 \\
(0.023)\end{array}$ & $\begin{array}{c}0.014 \\
(0.075)\end{array}$ & $\begin{array}{c}0.035 \\
(0.243)\end{array}$ & $\begin{array}{c}0.023 \\
(0.151)\end{array}$ \\
\hline Death in window & $\begin{array}{c}0.068 \\
(0.044) \\
\end{array}$ & $\begin{array}{c}0.007 \\
(0.005) \\
\end{array}$ & $\begin{array}{l}-0.014 \\
(0.010) \\
\end{array}$ & $\begin{array}{c}0.008 \\
(0.016) \\
\end{array}$ & $\begin{array}{c}0.010 \\
(0.012) \\
\end{array}$ & $\begin{array}{c}0.008 \\
(0.041) \\
\end{array}$ & $\begin{array}{c}0.131 \\
(0.132) \\
\end{array}$ & $\begin{array}{c}0.089 \\
(0.082)\end{array}$ \\
\hline $\mathrm{N}$ & 142260 & 223253 & 156135 & 144038 & 92609 & 130013 & 140923 & 140780 \\
\hline
\end{tabular}


The sample includes all women who have at least two births during the sample period.

"Naïve" OLS, Reduced Form, and IV specifications include controls for age of mother, maternal and paternal education, gender of child, birth order of child, and year of birth by month of birth dummies.

IV FE and IV Window FE specifications include mother fixed effects and exclude maternal age and education.

IV Window and IV Window FE specifications include a control for whether there is a grandparent death in the window around pregnancy.

The window around birth includes the year prior to conception, the 9 months post-conception, and the year subsequent to that.

All the IV specifications instrument the indicator variable for a death during pregnancy with an indicator variable for a death within 9 months of the conception date. 
Appendix Table 1

Parental and Birth Characteristics by Whether Death During Pregnancy

\begin{tabular}{|c|c|c|c|c|c|c|}
\hline & \multicolumn{2}{|c|}{ All } & \multicolumn{2}{|c|}{ No Death in Utero } & \multicolumn{2}{|c|}{ Death in Utero } \\
\hline & Mean & Std. Dev. & Mean & Std. Dev. & Mean & Std. Dev. \\
\hline Education of Mother & 13.19 & 2.69 & 13.19 & 2.69 & 12.86 & 2.76 \\
\hline Education of Father & 12.99 & 2.80 & 12.99 & 2.80 & 12.80 & 2.87 \\
\hline Age of mother at birth & 30.30 & 3.80 & 30.29 & 3.79 & 31.37 & 4.17 \\
\hline Month of Birth & 6.36 & 3.36 & 6.36 & 3.36 & 6.32 & 3.35 \\
\hline Year of Birth & 1994.18 & 9.54 & 1994.20 & 9.54 & 1992.64 & 9.53 \\
\hline Birth Order of Child & 2.10 & 1.04 & 2.09 & 1.04 & 2.26 & 1.13 \\
\hline Female & 0.48 & 0.50 & 0.48 & 0.50 & 0.48 & 0.50 \\
\hline$N$ & 785316 & & 776110 & & 9206 & \\
\hline
\end{tabular}

The sample includes all women who have at least two births during the sample period. 
Appendix Table 2

Means by Timing of Death

\begin{tabular}{|c|c|c|c|c|}
\hline & Death in Utero & Death Before & Death After & Death Before or After \\
\hline \multicolumn{5}{|l|}{ Parental and Birth Characteristics } \\
\hline Education of Mother & 12.86 & 12.79 & 12.79 & 12.79 \\
\hline Education of Father & 12.78 & 12.74 & 12.75 & 12.74 \\
\hline Age of mother at birth & 31.38 & 31.42 & 31.41 & 31.40 \\
\hline Month of Birth & 6.32 & 6.35 & 6.35 & 6.35 \\
\hline Year of Birth & 1992.68 & 1992.45 & 1992.49 & 1992.48 \\
\hline Birth Order & 2.27 & 2.26 & 2.25 & 2.26 \\
\hline Female & 0.48 & 0.49 & 0.48 & 0.48 \\
\hline Death during pregnancy & 0.99 & 0.01 & 0.03 & 0.02 \\
\hline Age at death (grandmother) & 69.25 & 69.20 & 69.74 & 69.51 \\
\hline Age at death (grandfather) & 67.82 & 67.20 & 68.30 & 67.75 \\
\hline \multicolumn{5}{|l|}{ Child Outcomes } \\
\hline Birth weight & 3585.63 & 3597.83 & 3604.19 & 3600.84 \\
\hline Log birth weight $(* 10)$ & 81.70 & 81.73 & 81.76 & 81.74 \\
\hline Fetal growth rate & 90.38 & 90.56 & 90.67 & 90.62 \\
\hline Weeks gestation & 39.58 & 39.65 & 39.68 & 39.66 \\
\hline Height (birth length) & 50.39 & 50.40 & 50.46 & 50.43 \\
\hline 5 minute APGAR score & 9.32 & 9.34 & 9.32 & 9.33 \\
\hline C-Section & 0.13 & 0.12 & 0.12 & 0.12 \\
\hline Neo-natal Ward & 0.04 & 0.04 & 0.04 & 0.04 \\
\hline Education (2010) & 13.36 & 13.38 & 13.41 & 13.39 \\
\hline Education $\geq 12(2010)$ & 0.85 & 0.84 & 0.85 & 0.84 \\
\hline Full time (2010) & 0.58 & 0.58 & 0.59 & 0.59 \\
\hline Log(earnings) in 2010 & 12.60 & 12.58 & 12.62 & 12.60 \\
\hline Log(earnings) full time workers 2010 & 12.91 & 12.92 & 12.92 & 12.92 \\
\hline IQ score at 18 & 5.35 & 5.37 & 5.35 & 5.36 \\
\hline Height at 18 & 180.55 & 180.54 & 180.38 & 180.45 \\
\hline BMI at 18 & 22.93 & 22.93 & 22.86 & 22.89 \\
\hline$N$ & 9116 & 11956 & 12966 & 24715 \\
\hline
\end{tabular}

Death in utero is 1 if a grandparent death occurs in the 9 months following conception. Death before is 1 if a grandparent death occurs in the 12 months before conception. Death after is 1 if a grandparent death occurs in the 12 months after the predicted due date. 


\section{Appendix Table 3}

Cause of Death during Pregnancy in Analysis Sample (Mother's Mother)

\begin{tabular}{lrr}
\hline & Number & Percent \\
\hline Cardiovascular Disease & 1755 & 35.06 \\
Cancer & 1097 & 20.66 \\
External Cause & 121 & 2.28 \\
Other Illness & 1068 & 20.12 \\
Unknown Cause & 1268 \\
Total & 5309 \\
\hline
\end{tabular}

Cause of Death during Pregnancy in Analysis Sample (Mother's Father)

\begin{tabular}{lrr}
\hline & Number & Percent \\
\hline Cardiovascular Disease & 3712 & 45.16 \\
Cancer & 1314 & 15.99 \\
External Cause & 158 & 1.92 \\
Other Illness & 1461 & 17.78 \\
Unknown Cause & 1574 \\
Total & 8219 \\
\hline
\end{tabular}


Appendix Table 4

Balancing Tests for Mother Fixed Effects Approach (IV Estimates)

\begin{tabular}{|c|c|c|c|c|}
\hline & $\begin{array}{c}\text { (1) } \\
\text { Father's Education }\end{array}$ & $\begin{array}{c}\text { (2) } \\
\text { Age of mother at birth }\end{array}$ & $\begin{array}{c}\text { (3) } \\
\text { Birth Order of Child }\end{array}$ & $\begin{array}{c}\text { (4) } \\
\text { Female Child }\end{array}$ \\
\hline Death in utero & $\begin{array}{l}-0.004 \\
(0.010)\end{array}$ & $\begin{array}{l}-0.030 \\
(0.059)\end{array}$ & $\begin{array}{l}-0.014 \\
(0.016)\end{array}$ & $\begin{array}{c}-0.003 \\
(0.008)\end{array}$ \\
\hline Death in window & $\begin{array}{c}0.008 \\
(0.005)\end{array}$ & $\begin{array}{l}0.948^{* *} \\
(0.032)\end{array}$ & $\begin{array}{l}0.212^{* *} \\
(0.009)\end{array}$ & $\begin{array}{l}-0.001 \\
(0.005)\end{array}$ \\
\hline$N$ & 785316 & 785316 & 785316 & 785316 \\
\hline
\end{tabular}




\section{Appendix Table 5}

IV Estimates using Mother Fixed Effects

\begin{tabular}{|c|c|c|c|c|c|c|c|c|}
\hline & $\begin{array}{c}(1) \\
\text { Birth } \\
\text { weight }\end{array}$ & $\begin{array}{c}\text { (2) } \\
\text { Log (Birth } \\
\text { weight) }\end{array}$ & $\begin{array}{c}\text { (3) } \\
\text { Fetal } \\
\text { Growth }\end{array}$ & $\begin{array}{c}(4) \\
\text { Weeks } \\
\text { gestation }\end{array}$ & $\begin{array}{c}(5) \\
\text { Height }\end{array}$ & $\begin{array}{c}(6) \\
5 \text { minute } \\
\text { APGAR }\end{array}$ & $\begin{array}{c}(7) \\
\text { C-Section }\end{array}$ & $\begin{array}{c}(8) \\
\text { Neonatal } \\
\text { Ward } \\
\end{array}$ \\
\hline \multicolumn{9}{|c|}{ Comparison: Before and After } \\
\hline Death in utero & $\begin{array}{c}-23.285^{* *} \\
(6.669)\end{array}$ & $\begin{array}{l}-0.072^{* *} \\
(0.022)\end{array}$ & $\begin{array}{l}-0.429^{* *} \\
(0.151)\end{array}$ & $\begin{array}{l}-0.089^{* *} \\
(0.026)\end{array}$ & $\begin{array}{l}-0.084^{* *} \\
(0.032)\end{array}$ & $\begin{array}{l}-0.029^{* *} \\
(0.014)\end{array}$ & $\begin{array}{l}0.013^{* *} \\
(0.004)\end{array}$ & $\begin{array}{l}-0.002 \\
(0.003)\end{array}$ \\
\hline Death in window & $\begin{array}{l}7.484^{* *} \\
(3.618) \\
\end{array}$ & $\begin{array}{l}0.024^{* *} \\
(0.012)\end{array}$ & $\begin{array}{l}0.153^{*} \\
(0.082)\end{array}$ & $\begin{array}{c}0.019 \\
(0.014) \\
\end{array}$ & $\begin{array}{l}0.062^{* *} \\
(0.018)\end{array}$ & $\begin{array}{c}0.004 \\
(0.008) \\
\end{array}$ & $\begin{array}{c}-0.003 \\
(0.002)\end{array}$ & $\begin{array}{c}0.001 \\
(0.002) \\
\end{array}$ \\
\hline \multicolumn{9}{|c|}{ Comparison: Death Before } \\
\hline Death in utero & $\begin{array}{c}-23.129^{* *} \\
(7.431)\end{array}$ & $\begin{array}{l}-0.070^{* *} \\
(0.025)\end{array}$ & $\begin{array}{l}-0.449^{* *} \\
(0.168)\end{array}$ & $\begin{array}{l}-0.079^{* *} \\
(0.029)\end{array}$ & $\begin{array}{l}-0.062^{*} \\
(0.036)\end{array}$ & $\begin{array}{l}-0.045^{* *} \\
(0.016)\end{array}$ & $\begin{array}{l}0.013^{* *} \\
(0.004)\end{array}$ & $\begin{array}{l}-0.002 \\
(0.003)\end{array}$ \\
\hline Death just before & $\begin{array}{c}7.120 \\
(4.893) \\
\end{array}$ & $\begin{array}{c}0.021 \\
(0.016) \\
\end{array}$ & $\begin{array}{c}0.169 \\
(0.111) \\
\end{array}$ & $\begin{array}{c}0.008 \\
(0.019) \\
\end{array}$ & $\begin{array}{c}0.037 \\
(0.024)\end{array}$ & $\begin{array}{l}0.020^{*} \\
(0.010) \\
\end{array}$ & $\begin{array}{l}-0.003 \\
(0.003) \\
\end{array}$ & $\begin{array}{c}0.001 \\
(0.002) \\
\end{array}$ \\
\hline \multicolumn{9}{|c|}{ Comparison: Death After } \\
\hline Death in utero & $\begin{array}{c}-23.171^{* *} \\
(7.439)\end{array}$ & $\begin{array}{l}-0.072^{* *} \\
(0.025)\end{array}$ & $\begin{array}{l}-0.403^{* *} \\
(0.169)\end{array}$ & $\begin{array}{l}-0.100^{* *} \\
(0.029)\end{array}$ & $\begin{array}{l}-0.101^{* *} \\
(0.036)\end{array}$ & $\begin{array}{l}-0.012 \\
(0.016)\end{array}$ & $\begin{array}{l}0.012^{* *} \\
(0.004)\end{array}$ & $\begin{array}{l}-0.002 \\
(0.003)\end{array}$ \\
\hline Death just after & $\begin{array}{c}7.147 \\
(4.790)\end{array}$ & $\begin{array}{c}0.023 \\
(0.016)\end{array}$ & $\begin{array}{c}0.122 \\
(0.109)\end{array}$ & $\begin{array}{c}0.029 \\
(0.019)\end{array}$ & $\begin{array}{l}0.077^{* *} \\
(0.023)\end{array}$ & $\begin{array}{l}-0.013 \\
(0.010)\end{array}$ & $\begin{array}{c}-0.003 \\
(0.003)\end{array}$ & $\begin{array}{c}0.001 \\
(0.002)\end{array}$ \\
\hline$N$ & 784385 & 784385 & 784385 & 785316 & 759988 & 732943 & 785316 & 759635 \\
\hline \multicolumn{9}{|c|}{$\begin{array}{l}\text { Standard errors in parentheses } \\
{ }^{*} p<0.10,{ }^{* *} p<0.05 \\
\text { The sample includes all women who have at least two births during the sample period. } \\
\text { All specifications include controls for age of mother, paternal education, gender of child, birth order of child, and year of birth by month of birth dummies. } \\
\text { These IV estimates instrument the indicator variable for a death during pregnancy with an indicator variable for a death within } 9 \text { months of the conception date. } \\
\text { Coefficients on log(birth weight) are multiplied by } 10 \text {. } \\
\text { Death in utero is } 1 \text { if a grandparent death occurs in the } 9 \text { months following conception. Death just before is } 1 \text { if a grandparent death occurs in the } 12 \text { months } \\
\text { before conception. Death just after is } 1 \text { if a grandparent death occurs in the } 12 \text { months after the predicted due date. }\end{array}$} \\
\hline
\end{tabular}




\section{Appendix Table 6}

IV Estimates without mother fixed effects for both the full and analysis samples

Full sample

\begin{tabular}{|c|c|c|c|c|c|c|c|c|}
\hline & $\begin{array}{c}\text { (1) } \\
\text { Birth weight }\end{array}$ & $\begin{array}{l}(2) \\
\text { Log (Birth } \\
\text { weight) }\end{array}$ & $\begin{array}{c}(3) \\
\text { Fetal } \\
\text { Growth }\end{array}$ & $\begin{array}{l}(4) \\
\text { Weeks } \\
\text { gestation }\end{array}$ & $\begin{array}{l}(5) \\
\text { Height }\end{array}$ & $\begin{array}{l}(6) \\
5 \text { minute } \\
\text { APGAR }\end{array}$ & $\begin{array}{c}(7) \\
\text { C-Section }\end{array}$ & $\begin{array}{l}\text { (8) } \\
\text { Neonatal } \\
\text { Ward }\end{array}$ \\
\hline Death in utero & $\begin{array}{c}-23.138^{* *} \\
(5.274)\end{array}$ & $\begin{array}{c}-0.077^{* *} \\
(0.017)\end{array}$ & $\begin{array}{l}-0.462^{* *} \\
(0.120)\end{array}$ & $\begin{array}{l}-0.073^{* *} \\
(0.019)\end{array}$ & $\begin{array}{l}-0.060^{* *} \\
(0.023)\end{array}$ & $\begin{array}{c}0.001 \\
(0.008)\end{array}$ & $\begin{array}{l}0.007^{* *} \\
(0.003)\end{array}$ & $\begin{array}{c}0.003 \\
(0.002)\end{array}$ \\
\hline$N$ & 1096597 & 1096597 & 1096597 & 1097918 & 1061691 & 1014128 & 1097918 & 1064850 \\
\hline \multicolumn{9}{|c|}{$\begin{array}{l}\text { Standard errors in parentheses } \\
{ }^{*} p<0.10,{ }^{* *} p<0.05\end{array}$} \\
\hline & $\begin{array}{c}\text { (1) } \\
\text { Birth weight }\end{array}$ & $\begin{array}{l}\text { (2) } \\
\text { Log (Birth } \\
\text { weight) }\end{array}$ & $\begin{array}{c}\text { (3) } \\
\text { Fetal Growth }\end{array}$ & $\begin{array}{c}\text { (4) } \\
\text { Weeks } \\
\text { gestation }\end{array}$ & $\begin{array}{l}(5) \\
\text { Height }\end{array}$ & $\begin{array}{l}(6) \\
5 \text { minute } \\
\text { APGAR }\end{array}$ & $\begin{array}{c}(7) \\
\text { C-Section }\end{array}$ & $\begin{array}{l}\text { (8) } \\
\text { Neonatal } \\
\text { Ward }\end{array}$ \\
\hline Death in utero & $\begin{array}{c}-22.172^{* *} \\
(6.095)\end{array}$ & $\begin{array}{l}-0.071^{* *} \\
(0.020)\end{array}$ & $\begin{array}{l}-0.398^{* *} \\
(0.139)\end{array}$ & $\begin{array}{l}-0.089^{* *} \\
(0.021)\end{array}$ & $\begin{array}{l}-0.055^{* *} \\
(0.027)\end{array}$ & $\begin{array}{l}-0.010 \\
(0.009)\end{array}$ & $\begin{array}{l}0.007^{* *} \\
(0.004)\end{array}$ & $\begin{array}{c}0.003 \\
(0.002)\end{array}$ \\
\hline$N$ & 784385 & 784385 & 784385 & 785316 & 759988 & 732943 & 785316 & 759635 \\
\hline \multicolumn{9}{|c|}{$\begin{array}{l}\text { Standard errors in parentheses. Standard errors are clustered by mother. } \\
{ }^{*} p<0.10,{ }^{*} p<0.05 \\
\text { The analysis sample includes all women who have at least two births dur } \\
\text { All specifications include controls for age of mother, maternal and patern } \\
\text { birth by month of birth dummies. }\end{array}$} \\
\hline
\end{tabular}

